\title{
Combat Training for Horse and Rider in the Early Middle Ages
}

\author{
Jürg Gassmann \\ Artes Certaminis and Schweizer Rossfechten-Verein
}

\begin{abstract}
The cavalry horse, tactics and training in Western Europe - the European provinces of the Roman Empire of the West and the Frankish Empire - during the Early Middle Ages (c. 500-1000) are still subject to many myths in both popular media and academic literature. Source material is admittedly thin, yet it is specific enough to allow us to correct many of these misconceptions and outright errors.

The article initially summarises the current state of knowledge on the war horse of the period, by reference to the archaeological record. It then reviews the cavalry's battlefield tactics, derives the skill level required to execute the manoeuvres described in the sources, and analyses where and how this training could have been provided.
\end{abstract}

The information gleaned provides an insight into the skills and expertise necessary to achieve the requisite sophisticated level of horsemanship. We shall argue that these imply a considerable investment in organisational infrastructure, personnel and institutional memory, which has so far not received much academic attention, and has wider implications for our view of the era.

Keywords - Cavalry, horses, horsemanship, tactics, military, training, Franks

\section{INTRODUCTION}

\section{I.1. Introduction}

This article will focus on a specific aspect of cavalry warfare: The tactics and performance of cavalry on the battlefield, and the training at the basis of both, between approximately 500 and 1000, and mainly in the area of Charlemagne's Frankish Empire.

Relevant European literature is scarce - apart from Hrabanus Maurus' incompletely preserved 9 ${ }^{\text {th }} \mathrm{C}$ epitome of Vegetius' de re militari, ${ }^{1}$ there is no text on cavalry training or riding after the treatises by Vegetius and Arrian, until the genre regains prominence first

\footnotetext{
${ }^{1}$ Hrabanus Maurus; Jeffrey Forgeng in Duarte I, Horsemanship, pp. 39-40; Gillmor, Practical Chivalry, pp. 9-10; Branderup, Academic Art, pp. 16-19. 
with Dom Duarte in the $15^{\text {th }} \mathrm{C}$ and then Federico Grisone in the $16^{\text {th }} \mathrm{C} .{ }^{2}$ For the European Early Middle Ages, we have to rely on the odd battle descriptions and archaeology.

There can be no doubt that European armies fielded genuine cavalry continuously since Late Antiquity; ${ }^{3}$ the proposition that true cavalry disappeared with the Roman Empire and was not resurrected until Carolingian times is no longer tenable. ${ }^{4}$ In this article, I shall not dwell on the putative size of armies, but I am accepting as given that the mounted contingents were large enough to act as cavalry, and thus to require specific cavalry tactics. I also do not want to speculate on whether cavalry or infantry were dominant; in my view, the Carolingian miles was primarily a highly trained fighter, capable of fighting on foot or mounted as the situation or the commander's tactical disposition demanded. ${ }^{5}$ Success in battle was premised on the tactically correct integration of the different weapons, which required both a grasp of the available tactical options at command level and the ability to execute the tactics at unit level.

It has to be borne in mind that the set-piece field battle was comparatively rare. The main preoccupations of the mediaeval mounted fighter were raids on enemy infrastructure, crops, herds, or supplies; protection of the own lines of communication and logistics; foraging; and reconnaissance. ${ }^{6}$ The typical military action in the Middle Ages was the siege - there as well, cavalry had an important role in enforcing the blockade, interdicting supplies to the besieged place and messengers leaving, ${ }^{7}$ as well as foraging for the besiegers and reconnoitring for potential relief forces; but these were minor, skirmish-

2 Forgeng in Duarte I, Horsemanship, pp. 13-15; Branderup, Academic Art, pp. 16-19. Byzantium produced a wealth of military literature, with references to cavalry tactics and training, continuously during its existence, and after the Crusades, the furusiyya-treatises appear in the Islamic domains: Gassmann, Mounted Encounters, pp. 88-90 and references; Verbruggen, Cavalry, pp. 51-53. Especially the $6^{\text {th }} \mathrm{C}$ Strategikon (attributed to Emperor Maurice) provides interesting information on Frankish and Byzantine tactics. Arrian's cavalry games: Junkelmann, Reiter II, pp. 175-182. One furusiyya treatise, The Way Horsemen Are by Ali ibn Abdurrahmen ibn Hodeil (Hudhayl al Andalusi), was written ca. 1361 in Europe, in Granada.

${ }^{3}$ Coupland, Carolingian Army, pp. 61-63; Halsall, Warfare, pp. 184-188.

${ }^{4}$ Essentially the proposition of Heinrich Brunner, and supported by R.H.C. Davis or Ann Hyland; discussion and references with Gassmann, Mounted Encounters.

${ }^{5}$ Halsall, Warfare, p. 181; Verbruggen, Cavalry, pp. 60-61. At the battle of Tours and Poitiers 732, Charles "Martel" had his Franks exclusively on foot: Bachrach, Carolingians, pp. 170-178; Gassmann, Mounted Encounters, p. 92. See also the battle at the Dyle, Fn. 59.

${ }^{6}$ Settia, Rapine, pp. 31-33; Gassmann, Role of Cavalry, pp. 159-166 and passim; but cf. Verbruggen and Halsall, Fn 8.

${ }^{7}$ Bachrach/Bachrach, Warfare, p. 243; Bachrach, Caballus et Caballarius, p. 184; Verbruggen, Cavalry, p. 65; Settia, Rapine, pp. 80-83, 87-94. Gassmann (Role of Cavalry) argues that the siege was the consequence of the cavalry's failure to first capture the castle in a lightning raid, and then persuade the occupiers to surrender as a consequence of the cavalry's devastation of the countryside. 
type actions, not involving large cavalry formations. The 19th $\mathrm{C}$ historians' will-o'-thewisp of the majestic, all-deciding field battle carried by the steamroller charge of serried knights has been deservedly banished, and I do not propose to resurrect it.

Still, field battles - including decisive ones - did occur, and when they did, the cavalry's performance often swung the outcome. ${ }^{8}$ Success depended on the cavalry being able to execute manoeuvres that, it will be argued, required intensive practice and advanced levels of horsemanship. This article will review the equine stock available to the early mediaeval miles, consider the battlefield tactics, derive the skill level required, and analyse where and how this training would have been provided.

\section{I.2. Human Height}

I shall show that horse heights in the Middle Ages were on average smaller than today; it is sometimes argued that mediaeval man, too, was shorter, and so the proportions are preserved. However, that is not so; in the Early Middle Ages, humans were not significantly shorter than they are today: The average height for a north-western European male in the $9^{\text {th }} \mathrm{C}$ was $173.4 \mathrm{~cm}$ (i.e. 5'8'). That declined to about $167 \mathrm{~cm}\left(5^{\prime} 5^{\prime \prime}\right)$ in the $17^{\text {th }}$ and $18^{\text {th }} \mathrm{C}$. Not until the early $20^{\text {th }}$ did height recover to $9^{\text {th }} \mathrm{C}$ levels. ${ }^{9}$

\section{I.3. Terminology}

\section{Conformation}

"Conformation" refers to a horse's build and proportions, and is defined by its skeletal structure and musculature. It determines a horse's carrying or pulling capabilities, and its range of movement. ${ }^{10}$ Modern breed registries specify the conformation requirements and preferences regarding an individual animal for the purposes of inclusion in the registry, and qualification as a breeding (especially stud) specimen.

A horse is - broadly speaking - "square" when the length of its legs equals the length of its back and its base (i.e. the distance between the front and back hooves when standing). ${ }^{11}$ Horses meant for pulling tend to have longer backs, runners a longer base.

\section{Collection}

"Collection" denotes a dynamic tension in a horse's attitude, especially during movement - the dynamic equivalent of the human's static "fighting stance". Whereas normally, a horse puts more weight on the forehand, in collection, a horse's energy is evenly balanced between the forehand and the hind. This balance gives it lightness, allows it to more

\footnotetext{
8 Verbruggen, Cavalry; Halsall, Warfare, pp. 156-161.

9 Steckel, Dark Ages, p. 216; Baillif-Ducros et al., pratique cavalière, p. 30.

10 Thomas, Conformation, pp. 1-6 and passim.

11 Thomas, Conformation, pp. 195-196 (with illustration).
} 
easily bear the load of the rider, and "soft feel" on the bit; it also enables it to move or turn suddenly, and with power, in any direction. Collection is externally manifested by an arched neck and "tucked-in" chin, though it has to be emphasised that this appearance is the result of collection, not its cause; forcing a horse's chin to tuck in will not cause it to collect (i.e. in true collection, the reins will hang, and not be taut).

Collection is fundamental to all high-level modern riding skills, including modern dressage, and like all dressage elements, it is an attitude horses take naturally. Still, it takes intensive training to teach a horse to come into collection on the rider's command, and further dedicated training to build a horse's muscles so that it is able to maintain collection for an extended time. ${ }^{12}$

\section{Gaits}

In this article, I distinguish between "canter" and "gallop". Gallop here means a headlong gallop, where a horse tries to run as fast as it possibly can, and its body cycles from extreme contraction to extreme extension. A canter has the same step cadence as a gallop, but is controlled both in its speed and its range of movement. A canter can be collected; a gallop never is. ${ }^{13}$

\section{Lead}

In canter and gallop, a horse's stride is "led" by either the front right leg or the front left leg; which "lead" a horse is on is crucial to turning: on a right lead, it is positioned to turn to the right (and vice versa). Turning left on a right lead is possible, but not without loss of power and speed, and if the horse is forced to do so at an inopportune moment (and the horse cannot adjust the lead), the rider runs the risk of throwing the rider or even the horse as well.

Changing lead while in a canter or a gallop - a "flying lead change" - is one of the finer accomplishments of horsemanship. If the rider times the cue correctly, the horse can change lead without loss of speed or power; a mistimed cue will at best disrupt the horse's stride. Tight turns (i.e. lead changes) while maintaining fluid motion showcase riders' ability to elegantly manage their mounts' lead. ${ }^{14}$

\section{Measurements}

A horse's height is measured at the withers, the more or less pronounced hump at the base of the neck. The traditional measure for height, historically across Europe and still used in the US, Britain or Ireland, is the "hand", where each hand is four inches, so

\footnotetext{
12 Branderup, Academic Art, pp. 23-25, 39, 73-80, 102-103, passim; Thomas, Conformation, p. 248.

13 Thomas, Conformation, pp. 235-242.

14 Gillmor, Practical Chivalry, pp. 8-9 and 14-16; Branderup, Academic Art, p. 86; Thomas, Conformation, pp. 241-242; IWER, pp. 42-43, tests 12-22.
} 
equivalent to $10.16 \mathrm{~cm}(4 \times 2.54 \mathrm{~cm})$; different regions of Europe had slightly diverging definitions of the inch or Zoll.

For ease of reference, I shall give heights in US/British hands as well as metric; to avoid confusion with the decimal point, "14.2 hands" shall be rendered as " $141 / 2$ hands". Weights are given in metric and Imperial, where a pound is $0.454 \mathrm{~kg}$.

\section{Breeds}

The "breed" as we know it today, with a defined conformation (often also colour) and based on a stud book, is an artefact of modern times. Horses in Late Antiquity and the Early Middle Ages were classified by type or function. Having said that, it is borne out by numerous references that breeding was done in a controlled manner. ${ }^{15}$

\section{"Horses" v. "Ponies"}

In modern show and competition, horses below $14 \frac{1}{2}$ hands / $148 \mathrm{~cm}$ are classed as "ponies", regardless of breed or conformation. However, "pony" is a technical term that describes a certain sub-set of equines, distinguished from horses by such aspects as the shape of the head, body structure, thickness of coat, development, hardiness, metabolism, and - some might add - attitude. Ponies as a group tend to be shorter than horses, but there are ponies taller, and horses shorter, than $14 \frac{1}{2}$ hands. ${ }^{16}$

\section{Prices}

Various sources mention the price of a specific or a type of horse, and prices vary widely $;^{17}$ this subject requires differentiation by source, location and time, so cannot be addressed here. Still, I submit this article shows why a well-trained, intelligent and combat-wise horse would attract a substantial premium over the run-of-the-mill mount.

\section{I.4. Translations}

Translations are mine unless otherwise indicated.

15 Gassmann, Mounted Encounters, p. 78 and references; Arloth, Reiterkönigtum, pp. 43-48. Charlemagne's capitulare de villis, e.g. c.12-15 (No. 32; Capit. I, p. 84): usually twelve mares to a stallion, and crimes involving a stallion more severely punished: Title 38 of the Pactus legis Salicae of 507-511, MGH - LL nat. Germ. Vol. 4.1, Karl August Eckhardt (Ed.), (Hanover: Hahn, 1962), pp. 136-141; a formula for dowries from St Gall from about the 9th C: MGH - Formulae Merowingici et Karolini aevi, Karl Zeumer (Ed.), (Hanover: Hahn, 1886), No. 12 / p. 385.

16 Thomas, Conformation, pp. 302-303.

${ }_{17}$ Bachrach, Caballus et Caballarius, pp. 177-178; Claridge, Market, for late mediaeval England. 


\section{THE "WARHORSE"}

\section{II.1. Archaeology v. Other Sources}

In this chapter, I shall rely exclusively on the archaeological record - thanks to the practice of horse sacrifices, archaeology can provide us with reliable data on the horses in the Early Middle Ages. Since the burials are usually in the context of socially higherstanding individuals, the assumption is reasonable that the inhumed horse cadavers would reflect the higher, i.e. taller end of the spectrum. ${ }^{18}$

I have not reviewed artwork - depictions or statuary - of the time, as the witnesses are few, and the interpretation of the information is derivative of assumptions and fraught with pitfalls. E.g., using the same methodology in examining the Bayeux Tapestry, Bachrach arrives at 15-16 hands / 150-160 cm as the height for the Norman horses, while Bouet fixes it at about $140 \mathrm{~cm} / 13^{3 / 4}$ hands. ${ }^{19}$

\section{II.2. Horse Height}

Complete skeleton finds are rare, so most height data are derived from extrapolations from certain bones. While the science for those calculations is fairly solid, the information that can be gleaned is limited to height and to some extent build (i.e. stocky or light), but cannot provide information on conformation overall. ${ }^{20}$

Junkelmann (ca. 1990) placed the height of the late Roman fighting horse at approximately $14 \frac{1}{2}$ hands / $148 \mathrm{~cm}$, and confirmed in a programme of experimental archaeology that a horse of medium build, square conformation and weighing about $400 \mathrm{~kg} / 880 \mathrm{lbs}$ (in this case, Camargues), judiciously trained up, was perfectly capable of sustained performance as a late antique heavy cavalry horse. ${ }^{21}$

Audouin-Rouzeau in a 1995 article concludes that the average size of horses (fighting and civilian) was considerably taller in Roman times, and considerably smaller in the Early Middle Ages. ${ }^{22}$ For her article, she analysed the then-available data from all over Europe;

18 On horse burials: Kehnel, Sacrifice, esp. pp. 9-12; Cross, Anglo-Saxon Burials; Buhrs, Noble Steeds, p. 46 and passim; v. Babo, Drantumer Müble, pp. 9-27.

19 Bachrach, Caballus et Caballarius, pp. 174-177; Bouet, Bayeux, p. 6.

20 See discussion on methodology, its limitations and margins of error in Becker, Rullstorf, p. 8; v. Babo, Drantumer Müble, pp. 141-143.

${ }^{21}$ Junkelmann, Reiter I, pp. $43-44$ and 250-253; the $2^{\text {nd }} / 3^{\text {rd }} \mathrm{C}$ skeleton evaluated by Lignereux et al., cheval Roder, pp. 382-383 was a lightly-built gelding of $13 \% 3$ hands / $140 \mathrm{~cm}$, the 10 -year-old, lightlybuilt $2^{\text {nd }} \mathrm{C}$ mare in Lignereux/Bouet, Iwuy horse, p. 39, stood at 141/4 hands $/ 143.5 \mathrm{~cm}$.

22 Audoin-Rouzeau, Compter et mesurer: 150-160 cm / 15-16 hands in Roman times, 126-127 cm on average (12/1/2 hands) in the Middle Ages; p. 280 for the dataset, p. 282 for the comparison, but acknowledging that the Early Middle Ages were thinly documented, p. 283. Similarly Rosengren, Iron Age Horse, p. 197. Junkelmann, Reiter I, p. 253, also finds a decline in size, but less marked. 
more recent articles on limited geographies and time periods provide a differentiated and, for our time and region, more consistent picture.

For early Anglo-Saxon England, Fern in 2005 and Cross in 2011 establish sizes between $130-145 \mathrm{~cm}\left(12^{3 / 4}-14 \frac{1}{4}\right.$ hands). ${ }^{23}$ On the basis of the 42 horse skeletons found at the $7^{\text {th }} / 8^{\text {th }} C$ Saxon burial site of Rullstorf near Lüneburg, Becker in 2007 finds sizes of 132 $148 \mathrm{~cm}\left(13-14 \frac{1}{2}\right.$ hands $) .^{24}$

Lepetz and Hanot in 2012 review the finds in France from the La Tène era to modern times, but include only one data point for the Early Middle Ages. ${ }^{25}$ Baillif-Ducros and Yvinec, writing in 2015 and focussing on early mediaeval north-western France, find less discrepancy between late Roman and early mediaeval times, and sizes closer to Junkelmann's. ${ }^{26}$

\section{II.3. Conformation}

Though the height of a horse is certainly important, conformation is a more relevant criterion. Among horses of a given height, it is conformation that determines the range of a horse's capabilities. A horse with a shoulder slope at a good angle has greater reach with its front legs, making it more agile and a better runner. ${ }^{27}$ A horse with a "tucked-under" pelvis (indicated by a low-set tail) has a better carrying ability, can maintain collection with greater ease and so has greater agility (i.e. better ability to move and turn). ${ }^{28}$ The length of the back, too, is important: a long-backed horse with a steep shoulder would be

${ }^{23}$ Fern, Anglo-Saxon Equestrianism; data from the table on p. 62, though the narrative on pp. 65-66 discusses a broader range on the lower end; Cross, Anglo-Saxon Burials, p. 193: 13-15 hands / 132$152 \mathrm{~cm}$, light build, 650-1,050 lbs / 300-500 kg; Cooke, Trading Identities, p. 15 has only one height $\left(14 \frac{1}{2}\right.$ hands / $\left.146 \mathrm{~cm}\right)$ for the seven Viking horse burial locations in Scotland.

${ }_{24}$ Becker, Rullstorf, p. 9; similar heights with Buhrs, Noble Steeds, p. 18, for two early mediaeval horses from Oegstgeest, Netherlands (131/2-141/2 hands / 136-144 cm), and with v. Babo, Drantumer Müble, pp. 142-143 for the $8^{\text {th }} / 9^{\text {th }} \mathrm{C}$ cemetery at Drantumer Mühle, Niedersachsen, Germany $\left(12^{1 / 2-}\right.$ $14 \frac{1}{2}$ hands / 126-143 cm), though measurements are tentative since her material was severely deteriorated.

${ }^{25}$ Lepetz/Hanot, Archéozoologie, pp. 16-17 - height $130 \mathrm{~cm} / 123 / 4$ hands, medium-light build.

${ }^{26}$ Baillif-Ducros/Yvinec, cheval de monte; also finding no significant difference in size Lignereux et al, cheval Roder, p. 382, or Lignereux/Bouet, Iwuy horse, p. 39. The Clos D'Ugnac site (Aude) yielded equidae skeletons from the Neolithic to the Late Middle Ages at the lower height range, but probably all working horses and donkeys: Bertin et al., Clos D'Ugnac horses, p. 184.

27 Becker, Rullstorf, pp. 14-15, 22; Becker finds the Rullstorf horses to have significantly more sloped shoulders than the contemporary Slavic-Avar horses, but not quite as sloped as modern horses, where achieving a slope approximating $45^{\circ}$ has been an avowed breeding objective.

${ }^{28}$ Due to the easy deterioration of the relevant bone material, Becker was not able to form a view on this feature - Becker, Rullstorf, p. 16. A short back being desirable for the $19^{\text {th }} \mathrm{C}$ cavalry horse: v. Krane, Remonten, pp. 22-23. Also Thomas, Conformation, p. 226. 
more adapted to pulling, while a short back and a "tucked-under" pelvis provide the square conformation, and with it the strength, power and agility so desirable for both combat and dressage - the hall-mark of the Iberian horse. ${ }^{29}$

Unfortunately, archaeological literature usually contents itself with a calculation of the horses' heights, with occasionally a reference to their build (i.e. whether they are more lightly-boned or "draughty"); so far as I can see, for the Middle Ages, only Becker has subjected her material to an analysis of the horses' possible conformation. ${ }^{30}$ The sizes established by Becker have been mentioned; her research on other aspects show the horses to tend to a medium-to-light build with an already fairly well-sloped shoulder. ${ }^{31}$ Only few intact skulls were available, some showing more robust, pony-type heads, the others a finer head associated with horses. ${ }^{32}$ Overall, the diversity of types does not allow the conclusion that the Early Middle Ages had a defined concept of breed.

\section{II.4. Weight and Carrying Capacity}

Size and conformation to a large extent determine the weight of a horse, and the carrying capacity of a horse is often derived as a factor of the horse's weight. A commonly applied standard, current in modern equine discourse, is that a horse should not consistently carry more than $20 \%$ of its body weight. Bachrach is emblematic for this paper-based approach: assuming that a man $(75 \mathrm{~kg})$ with saddle, rigging and tack $(15 \mathrm{~kg})$ and arms and armour $(30 \mathrm{~kg})$ weighs in at $120 \mathrm{~kg} / 250 \mathrm{lbs}$, the resulting horse would need to weigh at least $600 \mathrm{~kg}(1,250 \mathrm{lbs})$. Bachrach therefore puts the height of horses at between 15 and 16 hands. ${ }^{33}$

However, as shown, we need to assume the average war-horse to have stood in the range of $14-14 \frac{1}{2}$ hands / 140-145 cm; a horse of that height but a weight exceeding $600 \mathrm{~kg} /$ $1,250 \mathrm{lbs}$ would look grotesque. To uphold the ratio argument, one would have to assume that the (by now quite numerous and geographically dispersed) horse finds coincidentally or deliberately reflect the low end of the spectrum, and the real existing war horse was of the same types but in fact $1 \frac{1}{2}$ to 2 hands $/ 15-20 \mathrm{~cm}$ taller on average.

This is not persuasive; the weight/load ratio assumption has to give. Today, most horses are not worked hard daily and feeding cost and logistics are not as constrained, so $20 \%$

${ }^{29}$ Branderup, Academic Art, p. 80; Thomas, Conformation, pp. 195-196; Gassmann, Mounted Encounters, pp. 86-87.

${ }^{30}$ For the Middle Ages - for the Rodez Gallo-Roman horse, see Lignereux et al., Fn 21.

31 Becker, Rullstorf, pp. 10-13, though with a wide variance.

32 Becker, Rullstorf, p. 24 - pony/horse interpretation mine, not Becker's; similarly v. Babo, Drantumer Müble, p. 23.

33 Bachrach, Caballus et Caballarius, p. 177. Other authors suggest heights of 17 hands $/ 175 \mathrm{~cm}$. 
seems like a safe, if rough, rule of thumb. The situation for our forebears was very different. They could not afford to feed more horse than they strictly needed. ${ }^{34}$

Another faulty assumption is that to obtain a strong, battle-effective mount fit to carry an armed and armoured fighter, the horse would have to be cross-bred with draughts (e.g. Shire or Belgian - or the ever-popular Friesian, a carriage-horse). But heavy draughts do not make an appearance until the High to Late Middle Ages. Until the advances in agriculture, in rigging and tack, the pivoting axle and whippletree, and the mould-board plough, which came together from the $9^{\text {th }} \mathrm{C}$ onwards, the European heavy draught animal was the ox, not the horse. ${ }^{35}$ Anyway, draughts are built for just that: to pull, not to carry, and to plod or stride steadily, not to dance. ${ }^{36}$

\section{II.5. The Fighting Horse}

The archaeological record allows us to state with confidence that the mediaeval fighting horse was as a rule not taller than ca. $150 \mathrm{~cm} / 15$ hands, and definitely substantially taller than $120 \mathrm{~cm} / 12$ hands. ${ }^{37}$ Based on the literature cited above, the prime fighting horse from Late Antiquity until at least the High Middle Ages was probably 14 to at most 15 hands $(142$ to $153 \mathrm{~cm})$ tall, of medium build, weighing in the region of $400 \mathrm{~kg} / 850 \mathrm{lbs},{ }^{38}$ with a short back, well-sloped shoulder, and square conformation.

The inferred weight/load ratio was therefore $10: 3$, or $30 \%$ of the horse's body weight, which accords with academically conducted experimental archaeology, Napoleonic cavalry manuals ${ }^{39}$ and common sense. The $120 \mathrm{~kg} / 250 \mathrm{lbs}$ estimated above is anyway the load of a fully armoured eques; on a day-to-day basis, a rider on peacetime patrol

\footnotetext{
34 Still an issue in a Prussian cavalry manual of 1870 (where the author bemoans the "Gewichtshypochondrie" (weight hypochondria - riders seeking horses far larger than their needs) of his time): v. Krane, Remonten, p. 619-624, quote on p. 621. To revert to the logistics: A horse's feed requirements are directly proportional to its weight. A $600 \mathrm{~kg}$ horse will require $150 \%$ of the rations of a $400 \mathrm{~kg}$ horse (and, incidentally, produce $1 \frac{1}{2}$ times the manure of a $400 \mathrm{~kg}$ horse).

35 Claridge, Market, pp. 16-17; including military logistics: v. Mangoldt-Gaudlitz, Reiterei, pp. 45-46.

36 Thomas, Conformation, pp. 300-303. The $14 \frac{1}{4}$ hands / $143.5 \mathrm{~cm}$, lightly-built mare from the $2^{\text {nd }} \mathrm{C}$ treated in Lignereux/Bouet, Iwuy horse, p. 49, showed lesions pointing to improper harnessing of a horse that was not built for pulling in the first place. Also v. Krane, Remonten, p. 620.

37 The lower end is suggested e.g. by France, Warfare, p. 23.

${ }^{38}$ Lignereux et al. (cheval Roder, p. 385) estimate the weight of their horse to have been about $350 \mathrm{~kg}$ / 770 lbs; Becker does not hazard a guess at her specimens' weights.

39 Dawson, Remounts, p. 2 - in a letter to Dejean of $8^{\text {th }}$ January 1807, Napoleon instructed that horses for the light cavalry were to measure $13 \frac{1}{2}$ to 14 hands and five years old, and for the heavy cavalry 14 to $14^{3} / 4$ hands and four years old.
} 
would likely have been $20 \mathrm{~kg} / 45 \mathrm{lbs}$ lighter (eliminating most of the armour), bringing the load ratio for a $400 \mathrm{~kg} / 850 \mathrm{lbs}$ horse to a manageable $25 \% .40$

While a horse's carrying capability generally is predicated by its genetics, the specific individual's actual capacity is dependent on its opportunity to build a strong structure in adolescence (a function of its ability to move and its nutrition), and on its training. Consistently loading a horse at the $25-30 \%$ level is no doubt stressful, and there will be individuals for whom the load will be excessive - persistent over-loading will result in tell-tale skeletal lesions, which should be visible in the archaeology.

And they are: The Rullstorf horses range in age from $2 \frac{1}{2}$ to 20 . As one would expect from a policy of "pushing the envelope", Becker does identify over-burdening lesions. Still, only in one skeleton did she see a condition that very likely would have debilitated the horse within a few years, probably resulting from a combination of deprivation during adolescence and overburdening in adulthood. But this was only one of about 20 specimens where the condition of the material was sufficient to pass judgement - none of the samples showed pathologies that would have been debilitating at the time of the horse's death. ${ }^{41}$

And the training regime is paramount: one need only compare the professional cadre horses of the Spanish Riding School with their inductees; the trainees have the lithe appearance of the young track athlete, while the quadrille-level professionals have the physique of the rugby player.

\section{II.6. Remounts}

Training for a cavalry horse cannot sensibly begin until the horse is four years old, and will take 2-3 years to complete. ${ }^{42}$ Given the surely not very sensitive treatment a horse

40 See Thomas, Conformation, pp. 225-227: smaller, athletic horses have no trouble with $25 \%$.
41 Becker, Rullstorf, p. 30; virtually the same findings with v. Babo, Drantumer Müble, pp. 22-23; on the
other hand, Becker did not find a single case of osteochondritis dissecans, today a common
developmental disease (ibid., pp. $30-31$ ). No pathologies found by Buhrs, Noble Steeds, pp. 19 and $30-$
31. The skeleton of the 11 -year-old, $133 / 4$ hand / $140 \mathrm{~cm}$ lightly built horse from the $2^{\text {nd }} / 3^{\text {rd }} \mathrm{C}$
examined by Lignereux et al. (cheval Rodez, p. 385) also showed signs of overloading, as did the $14^{1 / 4}$
hands / $143.5 \mathrm{~cm}, 10$-year-old, lightly-built mare from the $2^{\text {nd }} \mathrm{C}$ treated in Lignereux/Bouet, Iwuy
horse: In Lignereux/Bouet's estimation, the lesions of the Iwuy working horse point to overloading
not from riding, but from pulling, exacerbated by improper harnessing of a horse that was not built
for pulling in the first place (p. 49 - they suspect the cause of death was complications from
strongyles). Tell-tale lesions are also visible in the rider, here a $6^{\text {th }} \mathrm{C}$ Frank in his twenties: BaillifDucros et al., pratique cavalière.

42 Gillmor, Equine Epidemic, pp. 39-41, referencing Columella's de re rustica, suggests riding training would have started at age 3, with horses ready for cavalry use at age 4; personally, I doubt that a horse would be physically (especially given the high loads) and psychologically mature enough for the strains of campaign at that age, but how exactly and at what ages training was done is not clear. 
would experience, its useful life would be up to about age 15 - it could still be ridden, but probably not on active duty. ${ }^{43}$ Bearing in mind attrition due to injury from accidents and combat or to illness, ${ }^{44}$ the average useful life must have been in the region of 6-7 years. Therefore, for every 100 cavalry, the remount service needed to graduate about 15 trained replacements every year. ${ }^{45}$

\section{BATTLEFIELD TACTICS AND HORSEMANSHIP}

\section{III.1. The "Cavalry Charge"}

It is an inescapable fact of mounted fighting that horse and rider together are bulky, and the horse is highly vulnerable. Tactical literature and Rossfechten manuals show that all mounted actions require the horse to be in motion; a stationary horse is a dead horse. ${ }^{46}$

But it is against the nature of a horse to ride into a solid obstacle, so the cavalry attack took one of two forms: Either the horse did a turn (a rollback, demi-pironette or volte-face) before it met the target, or it passed the target. ${ }^{47}$ There is no tactically correct third choice - crashing into the target, with horse and rider being cast down, is documented, but can hardly be called "tactically correct" as the fighter is rendered hors combat.

- Executing a rollback in front of the target has two challenges: Firstly, if executed at speed, both horse and rider must be prepared for it and execute it with deliberation and on the correct lead, or the rider or both will fall. Secondly, on the battlefield, horse and rider will be part of a larger unit. Even three horses

In working equitation competition, the minimum age is 6: IWER, p. 4. V. Krane, Remonten, specifies six months of "basic training" (p. 676) beginning at age 41/2 (p. 250), and approximately one year of further refinement while "on the job" (p. 679), by which time the horse will have completed most of its growth (p. 250); once "passed out", the further training focuses on the conditioning of the horse (p. 685). Branderup, Academic Art, pp. 42-43. Possibly, horses started off younger on "light duty" around the manor and were trained up for fighting later.

43 So also v. Krane, Remonten, p. vi - service age 5-15; Claridge, Market, p. 44 assumes a shorter service life for agricultural horses.

${ }^{44}$ See e.g. Halsall, Warfare, pp. 153-154, though Becker, Rullstorf, pp. 25-36, does not find any debilitating pathologies with her sample, with age ranges from $2 \frac{1}{2}$ to 20 .

45 Gillmor, Equine Epidemic, p. 42.

46 Verbruggen, Cavalry, p. 53, quoting Jean de Bueil's Jouvencel I, p. 153: “... ceulx qui assaillent et marchent à cheval, gaignent, et ceulx qui demeurent et actendent, perdent"'.

${ }^{47}$ This remained so into the $19^{\text {th }} \mathrm{C}-\mathrm{v}$. Krane's 1870 Prussian cavalry manual dismisses the notion of the "shock" collision of two cavalry units charging each other head on; somehow, the horses always contrived to pass each other. In such a situation, the big man on the massive horse had at best an - illusory - psychological edge; the side with the actual advantage was the one with superior agility of horse and training of trooper: v. Krane, Remonten, pp. 622-623. Also pointing out issues with larger horses: Thomas, Conformation, pp. 227-228. 
advancing in tight formation cannot execute a turn at the same time without bumping into each other.

This manoeuvre can come in two forms - either a complete, $180^{\circ}$ volte-face, or a $90^{\circ}$ wheel to the right or left; in the case of the wheel, the entire file would need to pass in front of the enemy formation, exposing it to missile attack.

- Passing the target requires the target to be loosely arrayed, as would be a foot unit fleeing or attacked from the flank, or a mounted unit. ${ }^{48}$

The attacking cavalry had to maintain a formation that was tight enough to appear as formation, i.e. to allow the equites to protect and support each other and dissuade an opponent from daring to venture into it, but flexible enough to give the attackers room to move and use their weapons. Once the equites managed to get among their victims, the faster and elevated cavalry, fighting with lance and sword, had the advantage. ${ }^{49}$

Cavalry could always attack cavalry - as Arrian observed, it is not possible to pack cavalry as tightly as infantry, and even if one could, it would be pointless since cavalry needs motion and space to be effective, ${ }^{50}$ so cavalry as a target presents the sufficiently loose array attacking cavalry needs.

Against infantry, cavalry would ideally only attack a formation already in disarray, as when it was fleeing, or by attacking from the flank or behind. ${ }^{51}$ A cavalry charge might have the psychological effect of causing infantry to disintegrate or flee before it, but against disciplined and tightly formed-up or even entrenched infantry, the first piece of advice seems to have been "don't do it" 52 - the inevitable result of cavalry riding into a solid infantry formation will be that the horse will get stuck in the midst of the infantry, and if the impact did not impale it on the infantry's pikes or spears, their Katabalger and Roßschinder ${ }^{3}$ will soon finish the job. Even if the infantry wanted to get out of the way, they couldn't - there is no-where to go, and not enough time. ${ }^{54}$

${ }^{48}$ Morillo, Age of Cavalry, p. 51.

${ }^{49}$ Morillo, Age of Cavalry, pp. 50-51.

50 Arrian c.24 in fine / p. 28; v. Krane, Fn. 47.

51 Jean de Bueil (Jouvencel I, p. 153) suggests that infantry on the move cannot maintain the tightness of formation that constitutes its strength.

52 Melzo (pp. 158-159); in that case, cavalry should dismount to attack.

53 The terms are anachronistic and belong to the Landsknechte of the Late Middle Ages, but are evocative: Roßschinder means "horse-knacker", and Katzbalger translates as "cat skinner", though "small horse" is attested to in Grimms Wörterbuch as alternative meaning for Katze.

54 Another argument against the "shock" attack into a solid infantry formation is that it cannot be trained; even if done without sharp weapons, it is too dangerous for man and beast on both sides, and what cannot be sensibly trained cannot be a regulation battlefield tactic. What can be observed in re-enactments is that horses will gravitate towards a perceived gap in the formation facing them, however small, and will (delicately but irresistibly) shove aside the infantrymen both sides of the 
This can be seen in the battle of Arques (1303), described in the Annals of Ghent: The Flemish commander, realising his mounted numbers were not large enough to allow them to operate as cavalry, ordered his knights dismounted and integrated with the infantry in a tight formation. The French cavalry, though strong, were limited to - ultimately unsuccessfully - probing the Flemish formation for gaps and weaknesses. Individuals from both sides who ventured out of formation were quickly cut down. ${ }^{55}$

Alternatively, the cavalry could use javelins or darts ${ }^{56}$ (later cross-bows and then pistols) to create gaps in the formation or provoke undisciplined counter-attacks; they would ride up to the infantry, throw their javelins, then ride back to pick up more javelins (or switch to lance), and ride in again, remaining in formation throughout. ${ }^{57}$ This manoeuvre appears to be described in a passage from the Carmen de bello Saxonico (probably winter 1075-76):

Procurrunt equites ex agmine regis alacres / Exultantque suis flectentes colla caballis Alternos ineunt discursus atque recursus, /Versuras celeres duplicantque decenter equestres Ac desiderio pugnandi bella lacessunt.58

\section{III.2. Interaction between Infantry and Cavalry}

But key to success in battle was the ability of infantry and cavalry to work together; in the early mediaeval battle line, the cavalry were usually positioned behind the infantry, enabling it to protect the infantry's back and flanks, and to exploit opportunities. ${ }^{59}$

gap (experiment done 2015 between the mounted Timetrotter crew and assorted legionary infantry at Augusta Raurica, and at Tournoi XIII; ref. also Bachrach, Carolingians, p. 95).

55 Annales Gandenses, p. 575; Bachrach, Caballus et Caballarius, pp. 189-192. To me, the Battle of Ghent is interesting not so much for the fact that the Flemish knights fought dismounted, there are ample sources in all periods for that, but for two other aspects: First, Guderian's principle “nicht kleckern, sondern klotzen" evidently applied to battlefield cavalry (i.e. contingents had to be sizeable to be effective); and secondly, the French cavalry failed to break the Flemish foot formation, despite having, in the absence of Flemish cavalry, all the leisure to try and do so. The French needed a victory, so by salvaging a draw, the Flemish ultimately won.

56 The lead-weighted plumbata referenced by Hrabanus Maurus (c.XI / p. 448).

57 Arrian c.59/pp. 60-61; described in Junkelmann, Reiter II, pp. 176-178 (with diagram).

58 Carmen de bello Saxonico, p. 1227, line 170: “The lively knights canter forward from the king's host / Rejoicing and arcing the necks of their horses / Taking turns to advance and fall back / And double skilfully in fast mounted turns / And with their desire for fighting they provoke battles." "Arcing necks" suggests the manoeuvre was done at a collected canter; at other times, authors use laxis habenis ("with loose[d] reins") to denote headlong flight or giving the horse its head in pursuit. Gassmann, Mounted Encounters, p. 85.

${ }^{59}$ Halsall is surely right to see this aspect as the key issue in the descriptions of the battle at the Dyle 891; the East Franks under King Arnulf faced entrenched Vikings across deep ground, so the 
A case in point is a battle of King Odo of West Francia against pirates in 892, described by Richer of Saint-Rémi. Facing well formed-up "Barbarian" (Norsemen or Viking) raiders on foot, Odo arranged his 6,000 foot and 10,000 horse with the infantry in front, the cavalry behind the infantry. The infantry advanced and first fired arrows into the Barbarians, then closed with spears. Once the Barbarian formation had been broken up, Odo's cavalry charged and annihilated the raiders.

But the battle was not over yet - the invaders had hidden a contingent of 4,000, which was advancing on the plundering and celebrating Franks. However, Odo's pickets discovered the force; on signal, the Frankish army reformed and saw off the attackers. ${ }^{60}$

The invaders were ship-borne, which would explain their lack of cavalry, and which almost certainly made victory easier for Odo, since his cavalry charge would not be disrupted by opposing cavalry; once they had land bases, the future Normans immediately set about building their own cavalry. ${ }^{61}$ But the report overall attests to Odo's competent generalship, not only in his initial tactical dispositions, but also in maintaining active reconnaissance, and the command-and-control ability to re-form his forces, even after the battle was supposedly won. ${ }^{62}$

Infantry and cavalry had to train the manoeuvres involved - on signal, the infantry had to create gaps in the formation to allow the cavalry to pass through from behind. In my view, training a horse to pass through an infantry formation, even a friendly one, requires intensive exercise, and cannot be done without.

\section{III.3. Formation Fighting on Horseback}

In order to maintain formation and to preserve the freedom to manoeuvre, all of the riders in the attacking formation would need to have their horses in at most a collected

only tactically correct option was to attack on foot. Arnulf's officers were concerned to still retain a cavalry reserve to guard against encirclement - Halsall, Warfare, pp. 186-188; Annales Fuldenses, pp. 119-121; Regino, pp. 137-138; v. Mangoldt-Gaudlitz, Reiterei, p. 40.

${ }^{60}$... peditum copias premittit, atque ex eis primum impetum infert. Ipse cum equitatu succedens, peditum fortunam opperiebatur. Nec minus et barbari acies ordinaverant, ac indivisi adversarios excipere cogitabant. At regii pedites hostibus directi, primo certamine sagittas iaculantur. Densatique lanceis obversis in illos feruntur. ... Post pedites vero et regius equitatus succedit, ac acies hostium, copiis peditum divisas, multo nisu irrumpit. ... Et cum iam potiretur victoria spoliisque diripiendis instaret, barbarorum IIII que insidiose in abditis latuerant, ex oblique viarum irruere. Qui cum gravido incesso propinquarent, armorum luce ab observatoribus cogniti sunt. Factoque signo exercitus in unum redit. Rex multo plures advenire arbitratus, suos hortatur stipatores, ut priores animos resumant, immo et non amittant. Richer, p. 44; v. Mangoldt-Gaudlitz, Reiterei, pp. 47-48.

${ }^{61}$ Verbruggen, Cavalry, pp. 61-62; see also the Edictum Pistense, Fn. 70; at the battle at the Geule 891, Viking cavalry (equites Nortmannorum) surprised the attacking Frankish infantry in the rear, and annihilated the Franks: Regino, p. 137; Halsall, Warfare, pp. 187-188, 210.

${ }^{62}$ It was Odo's military skill and success that allowed him to replace the deposed Charles the Fat as king in West Francia - Halsall, Warfare, p. 30. 
canter, on the same lead ${ }^{63}$ - in a headlong gallop, it is not realistically possible to maintain formation, or to remain on the same lead, and without collection, it is not possible to execute the pinpoint manoeuvres required.

Even without other stressors, being able to bring your horse into collection on command, and to control its lead while in movement, requires advanced horsemanship skills - not just an easy familiarity in the saddle (though that certainly helps), but acquired skill in horse and rider.

For the individual miles, maintaining formation discipline and calibrated speed is not just a challenge in terms of holding position relative to his comrades, but in terms of controlling the horse. Horses in a group tend to act as a herd. If one horse begins galloping, all will, and it is then exceedingly difficult to re-establish control (which explains why officers regularly dealt harshly with a trooper who broke ranks and dashed forward). ${ }^{64}$ Also, a stampeding herd is liable to overlook obstacles such as ditches, ${ }^{65}$ caltrops or stakes, and will be upon them before they can react.

This is also relevant to the "feigned retreat": the tactic itself is banal, children on the playground come up with it. The challenge is for the cavalry to "flee" convincingly - i.e. fast and messily - enough to trick the defenders into abandoning their formation, and once that has happened, the cavalry need to be able to react promptly to their commandant's signal to stop, turn around, re-form, and attack. ${ }^{66}$

\section{III.4. More Examples from the Sources: the Good, the Bad and the Ugly}

A frequently quoted source in the context of mounted formation training is the exercise described by Nithard around 840 :

Ludos etiam hoc ordine saepe causa exercitii frequentabant. [...] primum pari numero Saxonorum, W asconorum, Austrasiorum, Brittonorum, ex utraque parte, veluti invicem adversari sibi vellent, alter in alterum veloci cursu ruebat. Hinc pars terga versa protecti umbonis ad socios insectantes evadere se velle simulabant, at versa vice iterum illos, quos fugiebant, persequi studebant, donec novissime utrique reges cum

63 Gillmor, Practical Chivalry, pp. 8-9 and 12-13.

${ }^{64}$ According to Ekkehard (p. 138), this is how Chunibert died: Travelling, the aging churchman went ahead on his ambler. His servants galloped to catch up, and as the ambler heard the galloping hooves approaching from behind, it too began to gallop. Chunibert tried to control his horse, but was thrown and killed: Ministri autem ... sibimet a longe in equis curracibus luserant, tandemque post illum [Chunibertum] accelerabant. Ambulator autem cui insederat, alacritatem equorum post se sentiens, caput concutiens exultare cepit, atque ille cum eum urgueret, ne curreret, exiliens gravem senio et corpore virum deiecerat.

65 At the battle at the Unstrut (531), the Thuringians had prepared camouflaged ditches on the battlefield. The attacking Frankish horse initially fell into the ditches with heavy losses, but then advanced more cautiously and inflicted a decisive defeat: Gregory of Tours (III. 7), p. 114.

${ }^{66}$ Halsall, Warfare, p. 205. 
omni iuventute ingenti clamore equis emissis astilia crispantes exiliunt et nunc his, nunc illis terga dantibus insistunt. ${ }^{67}$

Clearly, this was training for battlefield manoeuvres, and the riders must have been able to change direction on command, in formation, and at (controlled) speed. ${ }^{68}$

The inclusion of the Saxons and Bretons is interesting considering the ignominious Breton Campaign of 851 of Charles the Bald at Juvardeil / Jengland just a decade later, described by Regino of Prüm:

Pugna committitur, Saxones, qui conducti fuerant, ad excipiendos velocium equorum anfractuosos recursus in prima fronte ponuntur, sed primo impetu spiculis Brittonum territi in acie se recondunt. Brittones more solito buc illucque cum equis ad buiuscemodi conflictum exercitatis discursantes modo confertam Francorum aciem impetunt ac totis viribus in medio spicula torquent, nunc fugam simulantes insequentium nibilominus pectoribus spicula figunt. Franci, qui comminus strictis gladiis pugnare consueverant, attoniti stabant, novitate ante inexperti discriminis perculsi, nec ad insequendum idonei nec in unum conglobati tuti. Nox superveniens bellum diremit. Multi ex Francis interfecti, quamplurimi vulnerati, innumerabiles equi perierunt. ${ }^{9}$

${ }^{67}$ Nithard (III. 6.), p. 38: "They also attended games [arranged for the purpose of] military exercise of the following nature: [...] first an equal number of Saxons, Gascons, Austrasians and Bretons, from both sides [i.e. Western and Eastern Frankish Empire], rode at each other in a fast gait, as if they wanted to attack each other. This side, turning around and with their shields protecting [their backs], pretended to want to escape from their pursuing comrades, and vice versa again sought to pursue those whom they [before] were fleeing, until finally both kings [Charles II the Bald and Louis the German] with all the youth, with enormous shouting, galloping horses and brandished spears surged forward and pursued first the one and then the other party."

68 Gassmann, Role of Cavalry, p. 151; Gillmor, Practical Chivalry, pp. 11-12; Halsall, Warfare, pp. 117118; v. Mangoldt-Gaudlitz, Reiterei, pp. 40-41; Bachrach, Merovingians, p. 121-131; idem, Carolingians, pp. 124-130; idem, Caballus et Caballarius, pp. 187-188 (though - notwithstanding the veloci cursu statement in the source, ref. Fn 104 - I query whether the manoeuvres were at high speed); Gassmann, Mounted Encounters, p. 85. The manoeuvre is already attested to the Celtic/Germanic tribes in Arrian's ars tactica (pp. 66-67; Junkelmann, Reiter II, p. 182).

${ }^{69}$ Regino, p. 79: "The battle is joined; the Saxons, who had been hired in, are placed in the first echelon to intercept the wide-ranging back and forth of the [Bretons'] fast horses, but terrified by the first attack of the Bretons' javelins, seek refuge in the battle-line. The Bretons in their usual manner run here and there through to every kind of contest with their lively horses, now they attack the solid battle-line of the Franks and with full strength launch javelins into its midst, now they feign flight yet punch javelins into the chests of the[ir] pursuers. The Franks, who were used to fighting up close with drawn swords, stood astonished, paralysed by the novelty of the fighting style which they had not experienced before, not appropriate for pursuit and not safely arrayed in one [formation]. Nightfall separates the battle. Many of the Franks are killed, even more injured, Acta Periodica Duellatorum 6(1), 2018 
The Bretons were renowned for their equestrian skills, and here deploy the key tactics of early mediaeval cavalry warfare: mobility and coordination; they do not attack the infantry formation head-on, but seek to disrupt it with javelins; they use feigned flight; they wait for the enemy formation to dissolve, then they strike.

Halsall maintains the Saxons were light infantry skirmishers, but that does not make sense - if Charles was expecting Breton cavalry, as Regino says, then light infantry would have been pointless, and surely Charles would not have had to go all the way to Saxony to hire skirmishers. The remark that the Saxons took refuge in acie (in the battle line) to my mind suggests that the Saxons were regular cavalry, since that is the regulation cavalry response when threatened (and Regino adds that Charles' host suffered high losses in horses); the Saxons may have expected the Bretons to fight as standard Frankish cavalry, and were dismayed by the - for them - unconventional tactics, though Regino also says the Bretons fought more solito (in their usual manner)..$^{70}$

King Henry I in preparation for the Battle of Riade 933 against Magyar horse-archers gave his cavalry the following "salutary" instruction, which was obeyed and allowed the Saxons to rout the Magyars:

Cum ad Martis proludium coeperitis properare, nemo sotium velotiori, quamquam babeat, temptet equo praeire. Verum clipeis altrinsecus operti primos super scuta sagittarum ictus recipite; deinde cursu rapido impetuque vehementissima super eos irruite, quatinus non prius vobis secundo sagittarum sentiant vulnera pervenisse. ${ }^{71}$

A description of a battle on the Dachtelfeld in the Süntel uplands, where the cavalry did not maintain controlled formation, is contained in the Revised Annals for the year 782:

[...] non quasi ad hostem in acie stantem, sed quasi ad fugientium terga insequenda spoliaque diripienda, prout quemque velocitas equi sui tulerat, qua Saxones pro

countless horses died." Gillmor, Practical Chivalry, pp. 10-11; Halsall, Warfare, p. 187; Bachrach/Bachrach, Warfare, pp. 294-295.

${ }^{70}$ Why Charles would have needed to buy in cavalry may be explained by the Edictum Pistense, where in c.26 (No. 273 of 25th June 864, Capit. II, p. 321) Charles laments that the lands exposed to the Vikings had lost so many horses that they were no longer able to field the required numbers of cavalry.

${ }^{71}$ Luidprand, pp. 51-52: "As you prepare to advance into battle, no-one should be tempted to ride faster than his comrade, even if he can. Indeed, cover yourselves with your shields and let the first flight of arrows hit the shields; then surge forward and break into them powerfully, so that they may feel themselves wounded before they can launch their arrows again." Bachrach, Caballus et Caballarius, p. 188; Bachrach/Bachrach, Warfare, p. 298. Disagreeing with Bachrach, "clipeis altrinsecus operti" to my mind means that the milites should not move their shields onto their backs, as was regulation for a cavalry advance (see Nithart / Fn 67; Bachrach, Carolingians, p. 197), but instead hold them over their horses' heads (as was Byzantine practice - Halsall, Warfare, p. 202) as protection from arrows from the front. 
castris in acie stabant, unusquisque eorum summa festinatione contendit. Quo cum esset male perventum, male etiam pugnatum est; nam commisso proelio circumventi a Saxonibus, paene omnes interfecti sunt.72

For the commanding officer, the challenge is to keep his formation's attention, retain the ability to issue orders, and have them promptly obeyed. At King Odo's battle (III.2), this obviously worked. In the Süntel episode, we do not know whether the commandant gave the tactically wrong order or whether the unit's training failed - either way, the cavalry acted tactically inappropriately, that fact was evident to the author of the Revised Annals, and the consequences were predictable. ${ }^{73}$

\section{III.5. Individual Horsemanship}

Cavalry recruits developed their agility by mounting wooden dummies with increasing equipment; these exercises had been elaborated by Vegetius and were included in Hrabanus Maurus' de procinctu - cavalry boot camp evidently contemplated structured training and dedicated facilities, both indoor and outdoor. ${ }^{74}$

In Chapter V, Hrabanus deals with formation training: For effectiveness in attack and defence, maintaining formation is critical, and formation can only be maintained at controlled speed; but haste may be advantageous in reconnaissance or to pre-empt the enemy's occupation of a key feature. From the vocabulary, it is not clear whether Hrabanus means foot or mounted - the corresponding passage in Vegetius, which Hrabanus adopts substantially unchanged, nearly certainly refers to infantry, but Hrabanus' introduction (which is not found with Vegetius) emphatically intends his instructions to refer to the

${ }^{72}$ Einhard, Annales, (year 782), p. 63: “As fast as each rider's horse could carry him, every single one of them galloped forward post-haste at the Saxons arrayed in front of their fort, not in the manner of attacking a formed-up enemy, but as if they were chasing after men fleeing, to win spoils. Since it was badly conceived, the fight went badly; as soon as battle was joined, they were surrounded by the Saxons and nearly all killed." Halsall, Warfare, p. 196; Bachrach, Carolingians, pp. 191-200; idem, Caballus et Caballarius, pp. 188-189; Verbruggen, Cavalry, pp. 59-60.

${ }^{73}$ Compare that to the charge of the British heavy brigade at Waterloo, the action that supposedly prompted the Duke of Wellington to observe that the only thing he could rely on his cavalry to do was to gallop too far and too fast. Though the charge was critically well-timed and succeeded in its immediate objective of halting the advance of D'Erlon's corps (potentially decisive for the battle overall), Uxbridge, in command of the cavalry, blamed himself for riding in the first echelon, where he was caught up in the mad dash that carried the heavy brigade beyond its objective into Napoleon's lancers and into destruction; he should have stayed in the second echelon, where he would have retained oversight over the battle and been able to pull back the first echelon, or lead a still-organised second echelon to confront the French cavalry: Mallia, Waterloo, pp. 6-12.

74 Bachrach, Caballus et Caballarius, pp. 186-187; idem, Carolingians, pp. 121-122; Hrabanus Maurus, c.XII / p. 448 (adopted substantially unchanged from Vegetius). Incidentally, this exercise is far easier to perform with a 14-hand horse than with a 16-hand horse. 
training of the eques. In any event, the principles apply equally to infantry and cavalry, especially the aspect that there is a time and place for haste, but where it is necessary to maintain formation, a more measured speed needs to be adopted. ${ }^{75}$ Hrabanus probably did not make a categorical distinction between "infantry" and "cavalry" anyway, as an eques was simply a trained fighter and capable of fighting on foot or mounted, and overall, his focus - as is evident from his non-Vegetian closing remarks - was to emphasise the vital importance of training and exercise.

Other than Hrabanus Maurus, we find only the odd reference to displays of horsemanship, such as the short passage with Ermoldus Nigellus, referring to a Breton:

Armat equum, semet, fidos armatque sodales, / Ambas missilibus armat et ipse manus, Scandit equum velox, stimulis praefigit acutis / Frena tenens; giros dat quadrupes varios. $^{76}$

Gillmor sees the Breton as showing off his horsemanship; if he was holding javelins in both hands, he must have controlled his horse by leg pressure and seat. In another source, the horsemanship display backfires:

... coepitque vertibilem equum modo impetus vehementi dimittere, strictis modo babenis retrahere. ... Cumque in eo esset, ut mutuis sese vulneribus figerent, more solito Bagoarius equo versili varios perplexosque per amfractus coepit discurrere, quatinus iis argumentis Hubaldum posset decipere. Verum cum hac arte terga verteret, ut mox rediens Hubaldum ex adverso percuteret, equus, cui Hubaldus insederat, vehementer calcaribus tunditur et per scapulas, antequam reverti Bagoarius posset, lancea ad cor usque perforatur. Hubaldus igitur freno Bagoaricum percipiens equim... ${ }^{77}$

\footnotetext{
75 Hrabanus Maurus, p. 445; Halsall, Warfare, p. 197, though I disagree with his views on the cavalry charge.

${ }^{76}$ Ermoldus Nigellus (in honorem Hludowici III. Line 375, early 9th C), p. 496: "He arm[our]s his horse, himself, and his loyal companions, and himself takes projectiles in both hands, quick he mounts his horse, pricks with sharp spurs while holding the reins; the horse performs various turns"; Junkelmann, Reiter III, p. 99. Gillmor, Practical Chivalry, p. 11.

77 Liudprand, p. 20 (C.21 - from the 889 war between Berengar I of Friaul, king of Italy, and Duke Wido III of Spoleto): “... he [the Bavarian] began to now let his agile horse surge forward, now reined it back hard. ... When they were in such a position that either of them could wound the other, the Bavarian began to run through his accustomed routine of varied and perplexing turns with his agile horse, confusing Hubaldus with these actions. Yet as he turned his back on Hubaldus in one of these moves, so that he might, in soon reversing, strike Hubaldus at a disadvantage, Hubaldus gave the horse on which he sat a sharp kick with the spurs and struck the Bavarian through his shoulder-blades to the heart before he could turn around. Hubaldus then took the Bavarian horse by the bridle..."; Gillmor, Practical Chivalry, pp. 13-14; Bachrach, Caballus et Caballarius, p. 193; Gassmann, Mounted Encounters, p. 86.
} 
Hubaldus could obviously read the Bavarian's intentions well enough that he could anticipate a favourable moment, and controlled his horse well enough that he was able to exploit it. Similarly, there is the following from the Ligurinus:

... vanamque superbus / Ostendans artem, rapido modo turbine vectus / Quadrupedantis equi, nunc certa lege reductis / In gyrum frenis, sinuosa volumina torquens / ... ${ }^{78}$

These passages all refer to displays of equine agility that were valuable in battle, whether single combat or formation. The mediaeval horseman was also sensitive to the individual horse's character: In 878, Bishop Solomon II of Constance wrote a letter to his colleague in Brixen, acceding to the latter's request for a top-quality horse, explaining the horse's needs if it were to achieve best performance on the battle-field and off, and giving some insight into its frame of mind. One of its traits: Et humano sensu cognoscat, quomodo sub quolibet homine se gerere debeat, hoc est sub iuvenibus et indisciplinatis transversus et supinus, sub senioribus vero et gravibus bumilis et rectus incedere norit. ${ }^{79}$

\section{LOCUS OF CAVALRY TRAINING}

\section{IV.1. Military Organisation from Late Antiquity to the Carolingians}

Already in Late Antiquity, magnates built up mounted personal followings that filled the military gap that resulted from the gradual disappearance of the professional Legionary heavy infantry. ${ }^{80}$ Much has been made of supposed changes through Merovingian and Carolingian times, and the introduction of feudal tenure as economic basis for the heavy, mounted knight. While there were organisational changes in the period, the theory that these changes brought a fundamentally new way of raising mounted troops has not stood the test of time. ${ }^{81}$

Into Carolingian times, the mounted fighting contingent seems to have been composed of three elements: The lord himself; the obsequium or comitatus, the lord's personal re-

\footnotetext{
${ }^{78}$ Gunther Poeta, p. 398: “.... and proudly showing vain art, [he was] carried in rapid gait in the whirl of his four-legged horse, now into a circle by firm technique of tightened reins, winding tangled paths, ...”. Gassmann, Mounted Encounters, p. 86.

79 "It is able to understand with human discernment how it needs to conduct itself under a given rider: under young and undisciplined riders, it holds back, but under experienced and serious ones, it knows to move obediently and properly" - Solomon II.

80 Morillo, Age of Cavalry, p. 53; Bachrach, Carolingians, p. 167; Sarti, Identität, pp. 313-314; Halsall, Warfare, pp. 44-50. In the border regions of Gaul, this process started already under Roman rule in the $4^{\text {th }} \mathrm{C}$; it only spread to the interior after the collapse of the Imperial administration: Sarti, Grenzgesellschaft.
}

${ }^{81}$ Halsall, Warfare, p. 71; Bachrach, Merovingians, pp. 28-29. 
tinue; $; 2$ and a third element assembled specifically for the campaign, sometimes referred to as a "select levy". 83 This select levy apparently comprised individuals within the lord's domains or sphere of influence who were, by status or census, obliged to render their military service in a mounted capacity when called up. It is of course possible that they were or at least included "graduates" from the retinue. Another possible scenario is that a person obliged to render mounted service by virtue of status or census could not (or did not want to) serve personally, because he or she was a woman, a cleric, old, infirm, exempted, too busy or had some other excuse, and fulfilled their obligation by sending a substitute; as is documented for later periods, such substitutes may well have been hired professionals or at least experienced fighters.

\section{IV.2. Organisation of Training for the Man}

A miles must obviously have experienced intensive training in order to be effective. How and where would such training be provided?

The royal court obviously could; Bachrach details three groups of mounted fighters within the court: The "cadet corps" of young nobles, being trained for military command; the "standing army" rapid reaction force; and the recruits in basic training. ${ }^{84}$ But the royal court can hardly have provided the cavalry training for all the kingdom's milites; the locus for tactical unit training had to reside with the retinue of the magnates. ${ }^{85}$

Bachrach ${ }^{86}$ describes the $7^{\text {th }}$ and $8^{\text {th }} \mathrm{C}$ town of Centula, outside the great monastery of $\mathrm{St}$ Riquier. One of the quarters of the town was reserved for the monastery's (mounted) milites, numbering about $110 .{ }^{87}$ For the purposes of this article, it is not relevant whether these milites were noble, free, vassals, mercenaries or unfree - the key point is that they constituted a permanent, "standing" force, and one large enough to require and justify an organisational and training infrastructure.

82 Halsall, Warfare, pp. 40-133; Bachrach, Carolingians, pp. 209-212 and passim. For Sarti, Identität, pp. 315-316, the personal retinue of magnates (re-)emerged as a military factor already in Late Antiquity, possibly re-invigorating Germanic tribal traditions. Also Wijnendaele, Warlordism.

83 Bachrach, Carolingians, pp. 54-56; similarly but more differentiated Halsall, Warfare, pp 72-77.

${ }^{84}$ Bachrach, Carolingians, pp. 65-76.

85 Halsall, Warfare, p. 45, 116; Hrabanus Maurus, c.III / p. 444: pueri et adholescentes in domibus principum nutriantur. Morillo, Age of Cavalry, p. 54-55, identifies the familia regis of the Anglo-Norman kings as a locus of systematic unit training. Coupland, Carolingian Army, p. 59, does not mention training, but refers to conscription, mobilisation and command.

86 Bachrach, Carolingians, pp. 62-65.

${ }^{87}$ By comparison, a modern $\left(19^{\text {th }} \mathrm{C}\right.$ ) cavalry squadron would number about 150 , commanded by a major and four additional officers in the ranks of captain and lieutenant, as well as numerous noncommissioned officers. 
Even without a campaign, a - lay or ecclesiastic - lord with extensive domains like St Riquier had a constant use for a gendarmerie: to assure the safety of the highways from brigands, to protect key infrastructure like mills, forges and bridges, to escort diplomats, dignitaries, merchants and tax collectors, to deliver messages, to corral escaped livestock, to keep down the wolf, deer and wild boar populations ${ }^{88}$ (which can cause herd and crop damage), and so on. The separation we make today between external security (military) and internal security (police) did not yet exist, and would not for several centuries. ${ }^{89}$ Troops of these milites would have been constantly on patrol, and not infrequently in skirmish-type action.

An establishment of this magnitude would have needed a steady supply of remounts. While it is reasonable to assume that the royal court was a "centre of excellence" for horse training, there is no evidence of an Empire-wide remount system - if there had been, this would surely have been addressed in the capitularies; in fact, the injunction on some establishments to contribute horses to the court points in the opposite direction.

Applying the replacement rates set out in II.6, for an effective strength of 110, command would have had to replace 16-17 horses every year. Such a workload occupies two, more likely three full-time trainers for that effort alone. It is also not an activity that could have been performed in a muddy field somewhere, but requires a reasonably-sized all-weather arena. While there is no unequivocal evidence that the training was conducted "inhouse", it had to have been conducted somewhere - horses do not instinctively take to the saddle.

\section{IV.3. The Indiculus Loricatorum and the Ecclesiastical Establishments}

The Indiculus Loricatorum,${ }^{90}$ a 981 Imperial chancery memo listing the re-enforcements to be mobilised by Emperor Otto II's magnates for his Italian campaign, provides an interesting insight.

88 Hunting yields familiarity with the local terrain and geography, practices application of weaponry and horsemanship, and requires co-ordination and leadership - all skills with immediate military application: Gassmann, Role of Cavalry, p. 154; Halsall, Warfare, p. 117. The Capitularium Aquisgranense (No. 77, c.8 - Capit. I, p. 170) from 801-813 requires each vicarius to employ, and provide fighting training to, two wolf-hunters, who were also exempt from call-up (though there is no mention of them being mounted); v. Mangoldt-Gaudlitz, Reiterei, p. 32.

${ }^{89}$ Sarti, Identität, p. 324 and Fn. 72 there, points out that in the Merovingian sources, miles typically refers to a gaoler, i.e. someone with a "police" function.

${ }^{90} \mathrm{It}$ is not exactly clear what is meant by loricatus; in the contemporary sources, there are frequent references to loricae (probably referring to a mail hauberk), but in my reading no suggestion that they necessarily implied a mounted fighter - on the other hand, a fighter obliged to serve mounted was also obliged to have a lorica (or brunia): Bachrach, Carolingians, p. 55. The total here is 20 fewer than in the MGH source since Werner, Heeresorganisation, pp. 834-835, argues that the reading of "XL" for St Gall is faulty and should be read as "XX". 
The Indiculus raises 2,030 loricati from 49 magnates - 40\% (20) of them secular, the remainder from abbeys $(11$, or $20 \%$ ) and bishoprics or archbishoprics $(18$, or $40 \%)$. The lay magnates contributed 25\% (556), the ecclesiastical magnates the rest $(1,474$, or $75 \%$ ). Within the ecclesiastical contingent, the abbeys provided another $25 \%$ of the total (422), while a good half $(1,052)$ came from bishoprics and archbishoprics. The latter also sent the largest contingents: the archbishops of Cologne, Mainz and Treves, along with the bishops of Strasbourg and Augsburg, each sent 100 fighters, a full 25\% of the total. ${ }^{91}$ All contingents are in multiples of ten (other than the smallest, which is 12), suggesting that ten was a tactical unit. ${ }^{92}$

Playing with the numbers, let us assume that a magnate would not have released more than $20 \%$ of his obsequium. As mentioned, the obsequium had a "day-time job" in the administration of the magnate's estates ${ }^{93}$ - sending away more than $20 \%$ would have caused excessive strain on the remaining man- and horsepower and, crucially, would have effectively eliminated training activity for the duration of the campaign. And if the

91 Also: Bertin et al., Clos D'Ugnac horses, p. 180; Bachrach, Merovingians, pp. 28-29; the only Carolingian marching orders extant, from the early $9^{\text {th }} \mathrm{C}$, are addressed to Fulrad, lay abbot of St Quentin (Karoli ad Abbatem Fulradum Epistola, No. 75; Capit. I, p. 168). The anonymous author of the vita Hludowici (pp. 334-337) complains that in 811 totius Aquitaniae ... clerus ... magis equitationi, bellice exercitationi, missilium librationi quam operam dare noverat quam divino cultui (the clergy of all Aquitania were more skilled at riding, military exercises and brandishing spears than attending to divine offices); v. Mangoldt-Gaudlitz, Reiterei, p. 17. Lesne, Notitia, p. 336 (Part 2) and p. 471 (Part 3), seems to suggest that monastic establishments with a significant military role would preferentially be given lay abbots. Werner, Heeresorganisation, pp. 805-808, shows that for military purposes, the ecclesiastical magnates were grouped within the regna of the Empire's secular organisation, not with the Church's diocesan structure.

$921^{\text {th }} \mathrm{C}$ Bologna used the decena as the standard base unit of cavalry: Gassmann, societates armatae, $\mathrm{p}$. 218 and references; Bachrach, Caballus et Caballarius, p. 192; Werner, Heeresorganisation, p. 837.

${ }^{93}$ I submit this is supported by c.27 of the capitulare missorum (Louis the Pious, 819; No. 141, Capit. I, p. 291): Ut vassi nostri et vassi episcoporum, abbatum, abbatissarum et comitum, qui anno praesente in boste non fuerunt, herbannum rewadient; exceptis his qui propter necessarias causas et a domno ac genitore nostro Karolo constitutas domi dimissi fuerunt, id est qui a comite propter pacem conservandam et propter coniugem ac domum eius custodiendam, et ab episcopo vel abbati vel abbatissa similiter propter pacem conservandam et propter fruges colligendas et familiam constringendam et missos recipiendos dimissi fuerunt (That our vassals and the vassals of bishops, abbots, abbesses and counts who have in this year not done military service should join the call-up; excepting those who have been sent home on important grounds and as provided by our father the Emperor Charles, that is those who were sent home by the [ir] count in order to keep the peace or protect their spouse or their home, or similarly by the[ir] bishop, abbot or abbess for the keeping of the peace, or gathering the fruits, or keeping control of the household, or bringing in the harvest). 
campaign took months, as an Italian campaign inevitably would, the knock-on effects of losing one year's worth of remount training would have been felt for years. ${ }^{94}$

Let us assume further that the estate would have provided half of the required contingent from the standing obsequium, the balance from "draftees" or the "select levy" obliged to render mounted service. ${ }^{5}$ Applying these factors, a magnate contributing a force of 100 would therefore have sent 50 from his "standing" force, meaning his standing force would have numbered $250 .{ }^{96}$

Having such an "equine reservoir" would also explain why the loss of $90 \%$ of the horses to illness in Charlemagne's Avar campaign of 791 could be overcome fairly quickly, though the losses (with other reverses) were bad enough that Charlemagne was effectively prevented from campaigning in earnest until autumn of $794 .{ }^{97}$

On a wider note, was the preponderance of ecclesiastical magnates reflective of the military organisation, or was it an artefact? Werner suggests it is an artefact: The contingents raised were reinforcements for the army already in Italy, and posits that the original callup would have fallen predominantly on the lay magnates. While a subject worth deeper study, the fact remains that the bishops and abbots played an important role in the raising, training and equipment of the Empire's cavalry. ${ }^{98}$

\section{SUMMARY, STIRRUPS, CONCLUSIONS AND OUTLOOK}

\section{V.1. Summary}

In this article, I set out to consider three inter-related issues: The conformation of the early mediaeval war-horse; the cavalry's battlefield tactics during the period; and the

94 Renard, politique militaire, p. 8, also uses a figure of $20 \%$, but does not make the differentiation between "standing units" and called-up ones. Werner, Heeresorganisation, pp. 832-837, by reference to other sources confirming selected allocations, shows that the contingents were not decided ad hoc, but reflected a fixed quota (though Werner argues these fixed quota were an Ottonian innovation and should not uncritically be read back into Carolingian times).

95 The Carolingian capitularia referenced by Renard, politique militaire, pp. 6-7, seem to allow for the categorisations outlined, but the terminology is anything but clear.

96 St Riquier would then have been allotted a force of 40 (putting it in the same league as Prüm, Freisingen, Constance, or Chur). Unfortunately, St Riquier was not within Otto II's domains, so we cannot test our assumptions, and anyway about two centuries stand in between. Still, the results do, I submit, stand the "laugh test", and unless we set the variables at opposite extremes, the resulting numbers are within the known data's order of magnitude.

97 Gillmor, Equine Epidemic; the illness was probably Eastern Equine Encephalopathy; that the magnates could contribute more if pushed: Werner, Heeresorganisation, pp. 829-836.

98 The Annales Bertiniani (for 866, p. 84) say that an army of Charles the Bald was predominantly made up of bishops' contingents (cum ... hoste confecta maxime de episcopis); Halsall, Warfare, p. 99. 
training required to put the cavalry in a position to execute those tactics. In the process, I have grazed far beyond the time frame I set out, yet not without method: The main objective was to show that the issues resulting from mounted combat did arise during the period under review; if the issue could be shown to have arisen, I allowed for outside-offrame sources to explain how they could be addressed.

Of course there were profound military, political, social, and technological changes during the period under review, and some of them have been referred to; some undoubtedly have an impact on the subject-matter, but could not be addressed. But a key point of this article, that is the mind of the horse and the challenges to its training, have, I maintain, not fundamentally changed, into our day.

Like all equine-focussed writers on the subject, I have approached the issue with my own baggage, and I have tried to remain conscious of the fact; no doubt other horse people will have their own, even violently disagreeing views on the opinions and conclusions presented - the field of modern equine training is at least as riven with ideological debate, schools and feuds as is the academia of mediaeval historians (one need only mention "natural horsemanship" or the Rollkur/hyperflexion controversy). Still, this is a discussion worth having; the subject is, I submit, so important, so fundamental to mediaeval history that it cannot simply be ignored.

\section{The Size and Conformation of the "War Horse"}

The archaeological record is now solid enough to state with confidence that the (early) mediaeval "war horse" was around 14-141/2 hands / 140-145 cm tall, and of medium build - a horse perfectly capable of carrying an armed and armoured fighter into battle, and of the agility required of a fighting horse. In my view more important than the physical description is the confirmation that Carolingian cavalry tactics required intensive, structured and expert training of both horse and rider.

\section{Riding Skills}

On the level of the individual horse and rider team, the skill required was considerably more sophisticated than for the Napoleonic cavalry trooper. Carolingian equites had to be able to bring their mounts into collection, on the correct lead, on command; they then needed to maintain formation in a collected canter for an extended period until contact with the enemy, execute a turn on command while wielding their weapons, and do all that over broken ground, not in the manicured manège, and while under fire.

But bringing a horse into collection or changing its lead in movement is not a "knack", a skill once grasped reliably reproducible, like riding a bicycle. It is also not a skill explainable in text, but one learnt by feeling and doing. Until the rider is sufficiently educated to feel their horse collecting, they require continuous supervised education of both horse 
and rider, by a sensitive and sophisticated master. ${ }^{99}$ It is not a skill that could have been imparted at occasional meets; horses and riders would have had to come to the manoeuvres already reliably solid, or they would have caused injury to their fellow mounts and riders.

One might object that locating such skills as collection and flying lead changes in the Early Middle Ages is anachronistic, that they did not make an appearance until the haute école of the $17^{\text {th }} \mathrm{C}$, as outlined by La Guérinière or Pluvinel. But that is misunderstanding the nature of the skills - all of them belong to the skill set expected in working equitation. There, they are of practical value, especially in managing cattle. The competition rules of the World Association for Working Equitation specify four tests: dressage, maneability (negotiating obstacles), speed (same obstacles), and working with cows. In the dressage segment, collected canter, flying lead changes and managing the lead while riding circles are integral to the test. ${ }^{100}$ In all disciplines, the competitor must at all times use only one hand on the reins, leaving the other free for tools. Of course, not every vaquero, gardian or cowboy performs at this level with ease; nor would have every miles in the obsequium. But there is absolutely no reason to assume that the skills were anachronistic, egregious or unattainable to a reasonably broad group of riders.

\section{Unit Tactics}

The unit tactics outlined by Nithard (and maybe Hrabanus Maurus) hearken back to the Roman-era cavalry unit techniques described by Vegetius and Arrian. They were unlikely a Carolingian re-invention - the techniques require riding skills, organisational infrastructure and institutional memory that are too sophisticated to be amenable to being re-created Empire-wide from scratch once lost. ${ }^{101}$ Given that Arrian ascribes many of the techniques to Celtic or Germanic practice in the first place, ${ }^{102}$ it is hard to see why the lapse of Imperial administration in the West should have entailed the loss of those skills among the Germanic successor kingdoms. More likely, the Carolingian high command resurrected Vegetius' instruction manual because it needed to weld the disparate elements of the Frankish host - the entourages of the various magnates, the Caro-

${ }_{99}$ Gillmor, Practical Chivalry, pp. 10 and 15-16; ead., Equine Epidemic, p. 41. Morillo, Age of Cavalry, p. 52 , in my view, underestimates the need for cavalry unit training.

100 WAWE official website: wawe-official.com. Rules from the IWER; the dressage tests are on pp. 42-43, tests 12-22.

101 The proposition that the riding skills were acquired from the Arab conquerors of Iberia is also not tenable: Gassmann, Mounted Encounters, esp. pp. 96-97 and references; Halsall, Warfare, p. 209.

102 Arrian, p. 49; Junkelmann, Reiter II, p. 175; Gassmann, Mounted Encounters, pp. 82-83; Einhard, Vita, (p. 455) says of Charlemagne: Exercebatur assidue equitando ac venando, quod illi gentilicium erat; quia vix ulla in terris natio invenitur, quae in hac arte Francis possit aequari (He [Charlemagne] exercised assiduously by riding and hunting, as was his birth-right; for there is hardly any people to be found in all the world which could equal the Franks in this art). 
lingian ministerials - into a cohesive fighting force; the new element was not the skills and techniques, but that they were practiced in an organised fashion across the organisational divides to instil an unité de doctrine for the entirety of the Frankish cavalry.

\section{Caveats}

A potential pitfall in using the sources is that we cannot be sure whether the authors are describing actual events or simply recycling literary topoi from Antiquity. ${ }^{103}$ This is a real risk, yet it need not be a binary matter - literary tradition was more strongly oral than today, and an author might have been subconsciously applying an appropriate remembered turn of phrase to an event observed.

I have not questioned the reliability of the sources, as that in and of itself entails an effort which available space did not allow, and the conclusion that an author is unreliable in one respect does not automatically mean he is unreliable in all. Instead, I have accepted each of them at face value, and relied on the diversity of the selection (more so in authors than in time). I submit that in the round, they present a consistent story, and impeaching any one of them would not change my conclusions. ${ }^{104} \mathrm{I}$ also did not find a source that would have been inconsistent.

Another caveat is whether the written manuals such as that of Hrabanus were ivorytower wishful thinking by clerical academics, without practical application or reflection in day-to-day reality. I believe were are on solid ground in firmly rejecting that view; for one, those same clerical academics were the individuals tasked with educating the next generation of military and political leaders. ${ }^{105}$ Also, the church establishments from which such military- and horse-savvy writers as Nithard, Einhard, Ekkehard, Solomon II or Regino hailed were, according to the Indiculus Loricatorum, also bases for the Empire's cavalry. Clerics were not (yet) removed from the fighting side of ruling, and there was considerable permeability between the senior lay and clerical ranks. Even if Nithard observed his cavalry manoeuvres through rose-tinted glasses, he knew exactly what the event was meant to look like; the Revised Annals' unvarnished inquest into the Battle in the Süntel could not have been written if the correct tactics had been purely theoretical.

\section{V.2. Side-Bar: Stirrups}

Conspicuously absent from the discussion has been any mention of stirrups; while stirrups become current in north-western Europe during the Early Middle Ages, their

103 E.g. Abels/Morillo, Lying Legacy?

104 Of all the sources, Nithard (III.4) to me is the most doubtful - I do not question the manoeuvres described, but rather the dramatic flawlessness with which they were supposedly executed, since the passage is part of a chapter where every aspect of this meeting between Charles and Louis is idyllic harmony and perfection.

105 Bachrach, Carolingians, p. 72 , 162. It is also noteworthy that $75 \%$ of the troops raised by Otto II were, according to the Indiculus Loricatorum, raised from ecclesiastical estates (IV.3). 
spread was gradual, and since they do not seem to have led to changes in military organisation, did not provide adopters with an obvious tactical advantage nor stimulate new tactics, I have not delved into the subject. For launching javelins or fighting with lance (at this time a fairly light weapon still used under-hand or over-hand, not couched) or sword, stirrups are not essential; if stirrups are needed for the couched-lance technique, it is not a sufficient condition, since the couched lance technique did not develop until the $11^{\text {th }} \mathrm{C}$, and then was very rapidly adopted.

Where stirrups are helpful is as an aid - the rider does not have to use his or her legs to hold on, but can focus on modulating leg pressure to provide instructions to the horse; it makes effective riding easier. ${ }^{106}$

\section{V.3. Conclusions}

It is always a challenge to demonstrate that military power lay not in superior numbers or material culture, but in "soft" factors that leave no traces in archaeology or museums.

At the level of the horse, ultimately, the determining factor that makes a fighting horse is not in its size or weight, but in its head: Certainly courage, ${ }^{107}$ the willingness to trust in the rider (which the rider needs to be able to justify to the horse) ${ }^{108}$ and overall a certain bloody-mindedness that means the horse is comfortable getting up close and personal with other horses, revolting townsfolk, riotous peasants, importunate bandits, enterprising cattle-rustlers, rebellious knights, pushy cows and obstreperous boars alike. But the key to the training is identifying the horses who - in addition to the conditioned responses and physical fitness to react to the rider's aids reliably and with alacrity - have the intelligence to understand what is expected of them. Like the accomplished polo pony who understands the game as well as the player, they are the ones who will hold up their own end in a fight, allowing the rider to concentrate on the opponent while the horse ensures that he is in the correct tactical position. ${ }^{109}$

There is evidence that the Western European cavalry horse was considered superior military technology - horses from the Baltic and Scandinavia were significantly smaller and

106 Gillmor, Practical Chivalry, pp. 14-15; also: Halsall, Warfare, pp. 173-174; Arloth, Reiterkönigtum, pp. 66-67. The proposition that the introduction of the stirrup drove the development of mounted "shock" combat and hence of feudalism was most famously propounded by Lynn White Jr. in his 1962 book Medieval Technology and Social Change, but is now no longer supported (discussion in Worthen, Lynn White, or Dibon-Smith, Stirrup).

107 Gillmor, Practical Chivalry, p. 9.

108 v. Krane, Remonten, p. 267; Erwin, Romance. That an intelligent, professional and responsible horse would make its willingness to take risks conditional on the competence and maturity of the rider was obviously already current in the Early Middle Ages, see Fn. 79.

${ }^{109}$ Dashper, Listening, esp. pp. 213-216; Erwin, Romance. For the polo pony: Kipling, Maltese Cat. 
the Teutonic Knights protected their monopoly on war-horses; ${ }^{110}$ horses from Eastern Europe had the same size but not the same agility-enabling conformation. ${ }^{111}$ The Edict of Pitres outlawed sale or other transfers of horses to the invading Norsemen, ${ }^{112}$ and Crusade-age Papal bulls similarly banned the export of military technology (including specifically Spanish horses) to the Arabs. ${ }^{113}$ Despite the cost and logistics involved, and the ready availability of horses locally, Crusaders made sure they had a constant supply of European horses. ${ }^{114}$

Yet in modern literature - even in works with a military history and even cavalry bent the horse rarely has more than a "walk-on" part. ${ }^{115}$ Given the central importance of the horse on the battlefield, for raiding, reconnoitring, communications, logistics and all manner of military jobs requiring mobility, this is a glaring omission. No history of the Second World War would disquire on the social origins of Fuller, Guderian, Patton and Zhukov, but then show no curiosity about the differences between the Matilda, the Sherman, the T-34, and the Tiger, or the main battle tank, the APC, and the Sturmgeschütr, and treat them all simply as "tank".

The élite Carolingian miles was primarily a highly trained fighter, capable of warfare on foot or mounted, as the terrain or the situation demanded. Success was a product of tactically correct choices, a judicious mix between the infantry's ability to seize and hold ground, and the cavalry's mobility and thus the ability to exploit opportunities or forestall enemy surprises by rapidly concentrating forces at a place of the commandant's choosing. The sources show that Carolingian cavalry benefited from a high level of training, which afforded Carolingian generals a rich tactical repertoire and thus a greater chance of success.

The brief outline presented here reveals that early mediaeval military high commands invested a considerable effort into the provision of highly trained horses for their cavalry, an effort that had to be continuous, consistent and structured; it was an effort that was built on institutional memory and expertise inculcated over the generations.

\footnotetext{
${ }^{110}$ In the region of 10-12 hands / 100-120 cm: Kontny et al., Elblag horses; Ekdahl, Horses and Crossbows, 122-124; Bertin et al., Clos D'Ugnac horses, p. 184; Rosengren, Iron Age Horse, pp. 197-198; Elsner et al., Iron Age Horses, p. 390, suggest that Celtic horses in Switzerland were no taller than $12 \frac{3}{4}$ hands / $130 \mathrm{~cm}$ before the Roman occupation, but subsequently above 14 hands / $140 \mathrm{~cm}$.

111 See Fn. 27.

112 Edictum Pistense Part B c. 25, 26 (No. 273 of 25 th June 864, Capit. II, p. 321) - the loss of horses had become so great that the affected regions could no longer field the required cavalry units.

113 Domínguez/Martínez, caballos hispanos, pp. 479-481.

114 Gassmann, Mounted Encounters, p. 96.

115 Erwin sees a similar phenomenon in literature analysis: Romance, pp. 42-43.
} 


\section{V.4. Outlook}

Clearly, this subject-matter deserves a more in-depth treatment. Specifically, the relevance of the ecclesiastical establishments as bases for the Carolingian Empire's cavalry, remount supply and training has not, so far as I can see, received much academic attention. ${ }^{116}$

Another area that may yield additional insights is literature, like the $W$ altharius (from St Gall, early $10^{\text {th }} \mathrm{C}$ - or the Ruodlieb, from Tegernsee, early $11^{\text {th }} \mathrm{C}$ ). Maybe the Waltharius is not merely, like Halsall (in line with the better view of scholarship) suggests, "monkish satire upon secular aristocrats and their silly boasting"; maybe it has a didactic element, where the cavalry-savvy instructor of one of the Empire's cavalry remount and training establishments wraps tactical and practical lessons into a (somewhat laboured) popular format so as to appeal to his audience of secular nobility. ${ }^{117}$

More generally, though, I would urge a broadening of our focus; too often, we look for immutable status: whether an individual in a particular position is an "aristocrat", "noble", "vassal", etc. As (arguably) suggested by Halsall and Bachrach, I would much rather see these concepts as steps in a career progression, and the obsequium as a structured body with a mix of squaddies, upwardly mobile commoners, time-servers, technically expert NCOs, and career officers. Maybe an individual started out as an unfree stable-boy, but through hard work and a good rapport with horses parlayed his skills into a respected assignment as remount training sergeant; a promising young noble might have graduated from the royal scara to subaltern in a bishop's obsequium to field officer on a campaign to a senior position on the Emperor's staff to lay abbot over an abbey with a strong cavalry element.

Perhaps that is how we need to read beneficium - not primarily as a question of feudal rights over land, but as a military commission; having invested the years and money for training an individual in effective warfare, high command would want to ascertain that he would in fact be available, and properly mounted and kitted out when needed. The obligation to serve, in the defined capacity, was a consequence of the training received, and the benefits of the position, be those rights over land or other sources of income, were tied to the position (not vice versa)?

\footnotetext{
116 On the ambiguous role of ecclesiastical establishments in the Frankish economy: Henning, Early European Towns, pp. 17-21. In the early mediaeval polyptychs, the dona dependent ecclesiastical estates were obliged to render were regularly measured in horses (or money - Hedwig, Eigenkirchen, esp. pp. 11-12; Arloth, Reiterkönigtum, pp. 56-58); a 780 agreement obliged St Gall to pay a rent of an ounce of gold and an (expensive) horse worth one pound to the Bishop of Constance (in E. Muhlbacher (Ed.), MGH - DD Kar. 1, (Hanover: Hahn, 1906), No. 130/pp. 179-180); not quite right Halsall, Warfare, p. 175.

117 Halsall, Warfare, p. 3; on the content (somewhat ambitiously) Bachrach, Carolingians, pp. 195-200; further literary references with Bourgain, Pratique, pp. 3-9; Erwin, Romance.
} 


\section{BIBLIOGRAPHY}

\section{VI.1. Primary sources}

Note: $\quad$ MGH $=$ Monumenta Germaniae Historica; standard MGH abbreviations used Annales Bertiniani [9th $C$ ], G. Waitz (Ed.), MGH - SS rer. Germ., Vol. 5 (Hanover: Hahn, 1883)

Annales Fuldenses [9th - early 10 th C], G.H. Pertz / F. Kurze (Eds.), MGH - SS rer. Germ., Vol. 7 (Hanover: Hahn, 1891)

Annales Gandenses [early 14th C], J. M. Lappenberg (Ed.), in: Annales Aevi Suevici, G. H. Pertz (Ed.), MGH - SS, Vol. 16 (Hanover: Hahn, 1859), 555-597

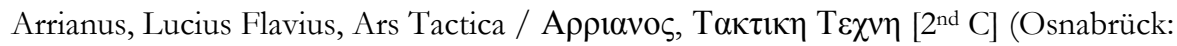
Biblio, $1967=$ facsimile reprint of Uppsala: Henricus Curio, 1664)

de Bueil, Jean, Le Jouvencel, [15 ${ }^{\text {th }}$ C] Léon Lecestre (Ed.), Vol. 1 (Paris: Renouard, 1887)

Capit. I Alfred Boretius (Ed.), MGH - Capit., Vol. 1 (Hanover: Hahn, 1883)

Capit. II A. Boretius, V. Krause (Eds.), MGH - Capit., Vol. 2 (Hanover: Hahn, 1897)

Carmen de bello Saxonico [probably winter 1075/76], O. Holder-Egger (Ed.), MGH - SS Vol. 15.2 (Hanover: Hahn, 1888), 1214-1235

Duarte I of Portugal, The Book of Horsemanship, [15 th C] Ed. and translation by Jeffrey Forgeng (Woodbridge: Boydell, 2016)

Einhard, Vita Karoli Magni [between 817-833], G. H. Pertz (Ed.), MGH - SS, Vol. 2 (Hanover: Hahn, 1829), 426-463

Einhard, Annales regni Francorum qui dicuntur Einhardi [1 st $^{\text {half }} 9^{\text {th }}$ C], G. H. Pertz / F. Kurze (Eds.), MGH - SS rer. Germ., Vol. 6 (Hanover: Hahn, 1895)

Ekkehard IV, Casus Sancti Galli - Continuatio [early 10 ${ }^{\text {th }}$ C], G. H. Pertz / Ildephons von Arx (Eds.), MGH - SS, Vol. 2 (Hanover: Hahn, 1829), 74-147

Ermoldus Nigellus [active 824-830], In honorem Hlodowici christianissimi caesaris augusti, G. H. Pertz (Ed.), MGH - SS, Vol. 2 (Hanover: Hahn, 1829), 464-523

Gregory of Tours, Historiae Francorum libri decem [late $6^{\text {th }} \mathrm{C}$ ] (Basel: Peter Perna, 1568)

Gunther Poeta, Ligurinus [late 12 $2^{\text {th }}$ C], E. Assmann (Ed.), MGH - SS rer. Germ., Vol. 63 (Hanover: Hahn, 1987)

Hrabanus Maurus, de procinctu Romanae miliciae [first half $9^{\text {th }}$ C], E. Dümmler (Ed.), Zeitschrift für deutsches Altertum, Vol. 15 (1872), 443-452

Indiculus Loricatorum Ottonis II in Italiam mittendorum [981], Ludwig Weiland (Ed.), MGH - Const., Vol. 1 (Hanover: Hahn, 1893), 632-633

IWER International Working Equitation Regulations 2017 < http://wawe-official.com/ ficheiros_artigos/wawe_regulations_2017(1).pdf $>$ (queried 14 ${ }^{\text {th }}$ November 2017) 
Kipling, Rudyard, The Maltese Cat (London: Macmillan, 1936)

v. Krane, Friedrich, Anleitung zur Ausbildung der Cavallerie-Remonten (Berlin: Mittler, 1870)

Liudprand of Cremona [ 920-970], Antapodosis, Joseph Becker (Ed.), MGH - SS rer. Germ., Vol. 41 (Hanover and Leipzig: Hahn, 1915)

Melzo, Ludovico, Regole militari sopra il governo e servitio particolare della cavelleria (Antwerpen: Ioachimus Trognaesius, 1611)

Nithard, Historiarum Libri IIII [842-843], G. H. Pertz / E. Müller (Eds.), MGH - SS rer. Germ., Vol. 44 (Hanover: Hahn, 1907)

Regino of Prüm [?-915], Chronicon, Friedrich Kurze (Ed.), MGH - SS rer. Germ., Vol. 50 (Hanover: Hahn, 1890)

Richer of Saint-Rémi [ 940-998], Historiarum Libri IIII, Hartmut Hoffmann (Ed.), MGH - SS, Vol. 38 (Hanover: Hahn, 2000)

Solomon II, Bishop of Constance, letter to Bishop Antonius of Brixen [early summer 878], in: Karl Zeumer (Ed.), MGH - Leges, Formulae Merowingici et Karolini aevi (Hanover: Hahn, 1886), 421-422

Vita Hludowici Imperatoris [mid 9th C], in: Ernst Tremp (Ed.), MGH - SS rer. Germ. 64 (Hanover: Hahn, 1995), 53-153

\section{VI.2. Secondary sources}

Abels, Richard, Stephen Morillo, 'A Lying Legacy? A Preliminary Discussion of Images of Antiquity and Altered Reality in Medieval Military History', in: Journal of Medieval Military History, Vol. 3 (2005), 1-13

Arloth, Jana, 'Pferde im Karolingerreich: Das Reiterkönigtum Karls des Großen', in: Frank Jacob (Ed.), Pferde in der Geschichte: Begleiter in der Schlacht, Nutztier, literarische Inspiration (Darmstadt: Büchner, 2016), 39-74

Audoin-Rouzeau, Frédérique, 'Compter et mesurer les os animaux. Pour une histoire de l'élevage et de l'alimentation en Europe de l'Antiquité aux Temps Modernes', in: Histoire \& Mesure, Vol. 10, 3-4 (1995), < DOI: 10.3406/hism.1995.1558 >, 277-312

v. Babo, Verena Freiin, Pferdebestattungen auf dem frübmittelalterlichen Gräberfeld Drantumer Müble (Gemeinde Emstek, Kreis Cloppenburg, Niedersachsen), Diss. Hannover 2004

Bachrach, Bernard S., 'caballus et caballarius in medieval warfare', in: Warfare and Military Organization in Pre-Crusade Europe (Aldershot: Ashgate, 2002), II (= The Study of Chivalry: Resources and Approaches, eds. H. Chickering and T. H. Seiler, Kalamazoo, 1988, 173-211) 
Bachrach, Bernard S., 'The imperial roots of Merovingian military organization', in: Anne Nørgård Jørgensen, Birthe L. Clausen (Eds.), Military Aspects of Scandinavian Society in a European Perspective, AD 1-1300: Papers from an International Research Seminar at the Danish National Museum, Copenhagen, 2-4 May 1996 (Copenhagen: National Museum, 1997), $25-$ 31

Bachrach, Bernard S., Early Carolingian Warfare: Prelude to Empire (Philadelphia PA: Penn, 2001)

Bachrach, Bernard S. and David S. Bachrach, Warfare in Medieval Europe: c. 400-c. 1453 (London \& New York NY: Routledge, 2017)

Baillif-Ducros, Christèle, M.-C. Truc, C. Paresys, S. Villotte, 'Approche méthodologique pour distinguer un ensemble lésionnel fiable de la pratique cavalière. Exemple du squelette de la tombe $11 \mathrm{du}$ site de «La Tuilerie » à Saint-Dizier (Haute-Marne), VI siècle, in: Bull. Mém. Soc. Anthropol. Paris, Vol. 24 (2012), 25-36

Baillif-Ducros, Christèle, Jean-Hervé Yvinec, 'Le cheval de monte aux VI ${ }^{\mathrm{e}}$-VII ${ }^{\mathrm{e}}$ siècles en Gaule du nord', in: Archeopages, 41 (2014-2015), 14-19

Becker, Ilona, 'Die Pferde aus dem sächsischen Gräberfeld Rullstorf (Ldkr. Lüneburg): eine anatomisch-paläopathologische Untersuchung und ein Vergleich mit rezenten Pferdepopulationen', in: Leipziger online-Beiträge zur Ur- und Frühgeschichtlichen Archäologie Vol. 27 (2007), 1-55

Bertin, Laëtitia, Palmira Saladié, Yves Lignereux, Anne-Marie Moigne, Nicolas Boulbes, 'The exploitation of equids in the middle ages on the Clos d'Ugnac archaeological site (Pennautier, Aude, France)', in: Journal of Archaeological Science: Reports, Vol. 15 (2017), 179-193

Bouet, Pierre, 'Les chevaux de la tapisserie de Bayeux', in: In Situ: Revue des patrimoines, Vol. 27 (2015), < DOI: 10.4000/insitu.11967 >, 1-24

Bourgain, Pascale, 'Pratique de l'équitation au Moyen Âge d'après les textes littéraires', in: In Situ: Revue des patrimoines, Vol. 18 (2012), < DOI: 10.4000/insitu.9721 >, 1-13

Branderup, Bent, Academic Art of Riding (Richmond-upon-Thames: Cadmos, 2014)

Buhrs, Elfi, Old Companions, Noble Steeds: Why Dogs and Horses were Buried at an Early Medieval Settlement Along the Old Rhine, MSc thesis Archaeology, Leiden 2013

Claridge, Jordan, Horses for Work and Horses for War: The Divergent Horse Market in Late Medieval England, Master Thesis University Edmonton AB, 2011

Cooke, Siobhan, 'Trading Identities: Alternative Interpretations of Viking Horse Remains in Scotland. A Pierowall Perspective', in: Papers from the Institute of Archaeology, Vol. 25(2)/Art. 16 (2016) < DOI: http://dx.doi.org/10.5334/pia-475 >, 1-15

Coupland, Simon, 'The Carolingian Army and the Struggle Against the Vikings', in: Viator: Medieval and Renaissance Studies, Vol. 35 (2004), 49-70

Cross, Pamela J., 'Horse Burial in First Millennium AD Britain: Issues of Interpretation', in: European Journal of Archaeology, Vol. 14 / Nos. 1-2 (2011), 190-209 
Dashper, Katherine, 'Listening to Horses: Developing Attentive Interspecies Relationships through Sports and Leisure', in: Society \& Animals, Vol. 25 (2017), 207-224

Dawson, Paul L., French Cavalry Remounts and Replacements December 1806 to December 1807, online < http:/ /www.napoleon-series.org/military/organization/France/Cavalry/ Remounts/c_remounts1806-1807.pdf > (Queried 17 November 2017)

Dibon-Smith, Richard, 'The Stirrup as a Revolutionary Device', in: Lynn Hunt (Ed.), New Ideas About the Past: Seven Essays in Cultural History (Berkeley and Los Angeles CA: University of California Press, 1989), 103-110

Domínguez Sánchez, Santiago / José Manuel Martínez Pérez, 'Los caballos hispanos en el siglo XIII y su presencia en las Cruzadas', in: Proceedings of the $37^{\text {th }}$ International Congress of the World Association for the History of Veterinary Medicine \& $12^{\text {th }}$ Spanish National Congress on the Veterinary History, 22-24 Sept. 2006, Faculty of Veterinary, León, Spain, 477-492

Ekdahl, Sven, 'Horses and Crossbows: Two important warfare advantages of the Teutonic Order in Prussia', in: Helen Nicholson (Ed.), The Military Orders, Vol. 2: Welfare and Warfare (London: Routledge, 1998), 119-152

Elsner, Julia, Sabine Deschler-Erb, Barbara Stopp, Michael Hofreiter, Jörg Schibler, Angela Schlumbaum, 'Mitochondrial d-loop variation, coat colour and sex identification of Late Iron Age horses in Switzerland', in: Journal of Archaeological Science: Reports, Vol. 6 (2016), 386-396

Erwin, Bonnie J., 'Beyond Mastery: Interspecies Apprenticeship in Middle English Romance', in: Exemplaria, Vol. 29/1 (2017), 41-57

Fern, Chris, 'The archaeological evidence for equestrianism in early Anglo-Saxon England, c.450-700', in: Aleksander Pluskowski (Ed.), Just Skin and Bones? New Perspectives on Human-Animal Relations in the Historical Past, (Oxford: British Archaeological Reports, 2005), 43-71

France, John, Western Warfare in the Age of the Crusades: 1000-1300 (London: UCL, 1999)

Gassmann, Jack, 'Thoughts on the Role of Cavalry in Medieval Warfare', in: Acta Periodica Duellatorum, Vol. 2 (2014), 149-177

Gassmann, Jürg, 'East meets West: Mounted Encounters in Early and High Mediaeval Europe', in: Acta Periodica Duellatorum, Vol. 5.1 (May 2017), 75-108

Gassmann, Jürg, 'The Bolognese Societates Armatae of the Late $13^{\text {th }}$ Century', in: Acta Periodica Duellatorum, Vol. 2 (2014), 195-231

Gillmor, Carroll, 'The 791 Equine Epidemic and its Impact on Charlemagne's Army', in: Journal of Medieval Military History, Vol. 3 (2005), 23-45

Gillmor, Carroll, 'Practical Chivalry: The Training of Horses for Tournaments and Warfare', in: Studies in Medieval and Renaissance History, 13 (1992), 7-29

Halsall, Guy, Warfare and society in the barbarian west: 450-900 (London: Routledge, 2003) 
Halsall, Guy, 'Two Worlds Become One: A 'Counter-Intuitive' View of the Roman Empire and 'Germanic' Migration', in: German History, 32/4 (2014), 515-532

Hedwig, Andreas, 'Die Eigenkirche in den urbarialen Quellen zur fränkischen Grundherrschaft zwischen Loire und Rhein', in: Zeitschrift der Savigny-Stiftung für Rechtsgeschichte, Kanonistische Abteilung, Vol. 78 (1992), 1-64

Henning, Joachim, 'Early European Towns: The development of the economy in the Frankish realm between dynamism and deceleration AD 500-1100', in: Joachim Henning (Ed.), Millennium Studies: Post-Roman Towns, Trade and Settlement in Europe and Byzantium, Vol. 1: The Heirs of the Roman West (Berlin/New York NY: de Gruyter, 2007), 3-40

Junkelmann, Marcus, Die Reiter Roms (Mainz: von Zabern) - Teil I: Reise, Jagd, Triumph und Circusrennen (1990); Teil II: Der militärische Einsatz. (1991); Teil III: Zubehör, Reitweise, Bewaffnung (1992)

Kehnel, Annette, 'Le sacrifice du cheval: Une brève histoire de sa découverte d'Hérodote à Dumézil', in: Bernard Andenmatten, Agostino Paravicini Bagliani, Eva Pibiri (Eds.), Le cheval dans la culture médiévale (Florence: Sismel, 2015), 5-32

Kontny, Bartosz / Jerzy Okulicz-Kozaryn / Miroslaw Petrzak, 'Horse graves in the Elblag group: The case of the cemetery at the Nowinka, Tolkmicko commune', in: Archaeologia Baltica, Vol. 11 (2009), 164-184

Lepetz, Sébastien and Pauline Hanot, 'Archéozoologie et patrimoine ostéologique du cheval. Les os des chevaux provenant des fouilles archéologiques : sujets de recherche et archives du sol', in: In Situ: Revue des patrimoines, Vol. 18 (2012), < DOI:

10.4000/insitu.10512>, 1-22

Lesne, Émile, 'Les ordonnances monastiques de Louis le Pieux et la Notitia de servitio monasteriorum', in: Revue d'bistoire de l'Église de France, Part 1: Vol. 6/31 (1920), 161-175; Part 2: Vol. 6/32 (1920), 321-338; Part 3: Vol. 6/33 (1920), 449-493

Lignereux, Yves, J. Peters, N. Périn, Ph. Gruat, 'Un cheval gallo-romain inhumé dans le cimetière du site de Notre-Dame du Bon Accueil ( $\mathrm{II}^{\mathrm{e}}-\mathrm{III}{ }^{\mathrm{e}}$ s. après J.-C., Rodez, Aveyron)', in: Revue de médecine vétérinaire, Vol. 149/5 (May 1998), 379-386

Lignereux, Yves, Cécile Bouet, 'Spinal hyperostosis and ankylosis in a Gallo-Roman horse from Iwuy 'Val-de-Calvigny' (Nord, France): 'Ankylosing spondylarthritis' (spondylarthritis ankylopoetica), 'deforming spondylarthrosis' (spondylarthrosis deformans) or 'DISH' (byperostosis vertebralis ankylopoetica)? An archeozoological and comparative nosological review', in: International Journal of Paleopathology, Vol. 9 (2015), 38-51

Mallia, Matthew, 'Galloping at Everything': Wellington and the British Heavy Cavalry Charge at $W$ aterloo, The Society for Army Historical Research 2016 Undergraduate Competition winner, < https://www.academia.edu/24874336/Galloping_at_Everything_Wellington_and_the_British_Heavy_Cavalry_Charge_at_Waterloo $>$ (queried $7^{\text {th }}$ May 2017)

v. Mangoldt-Gaudlitz, Hans, Die Reiterei in den germanischen und fränkischen Heeren bis zum Ausgang der deutschen Karolinger (Paderborn: Deutscher Geschichtsverlag, $2011=$ facsimile reprint of: Berlin: Weidmann, 1922) 
Morillo, Stephen, 'The “Age Of Cavalry” Revisited', in: Donald J. Kagay, L. J. Andrew Villalon, The circle of war in the Middle Ages: essays on medieval military and naval history (Woodbridge: Boydell \& Brewer, 1999), 45-58

Renard, Étienne, 'La politique militaire de Charlemagne et la paysannerie franque', in: Francia 36 (2009), 1-34

Rosengren, Erika, 'The Iron Age Horse', in: Charlotte Fabech / Ulf Näsman (Eds.), The Sösdala Horsemen and the equestrian elite of fifth century Europe (Højbjerg: Jutland Archaeological Society, 2017), 195-204

Sarti, Laury, 'Die spätantike Militärpräsenz und die Entstehung einer militarisierten 〉Grenzgesellschaft in der nordwesteuropäischen limes-Region', in: Christoph Rass (Ed.), Militärische Migration vom Altertum bis zur Gegenwart: Studien zur Historischen Migrationsforschung 30 (Paderborn: Schöningh, 2016), 43-56

Sarti, Laury, 'Die Identität des Kämpfenden nach dem Zusammenbruch des römischen Militärwesens in Gallien', in: Archiv für Kulturgeschichte, Vol. 95 (2013), 309-332

Settia, Aldo, Rapine, assedi, battaglie: La guerra nel Medioevo (Rome: Laterza, 2002)

Steckel, Richard H., 'New Light on the "Dark Ages": The Remarkably Tall Stature of Northern European Men during the Medieval Era', in: Social Science History, Vol. 28/2 (Summer, 2004), 211-229

Thomas, Heather S., The Horse Conformation Handbook (North Adams MA: Storey, 2005)

Thompson, E. A., 'Early Germanic Warfare', in: Past \& Present, 14 (Nov 1958), 2-29

Verbruggen, J. F., 'The Role of the Cavalry in Medieval Warfare', translated by Kelly DeVries, in: Journal of Medieval Military History, Vol. 3 (2005), 46-71

Werner, Karl F., 'Heeresorganisation und Kriegführung im deutschen Königreich des 10. und 11. Jahrhunderts', in: Structures politiques du monde franc (VIe-XIIe siècles): études sur les origines de la France et de l'Allemagne, (London: Variorum Reprints, 1979), No. III

Wijnendaele, Jeroen W.P., "Warlordism” and the Disintegration of the Western European Army', in: Jeremy Armstrong (Ed.), Circum Mare: Themes in Ancient Warfare, (Leiden/Boston MA: Brill, 2016), 185-203/283-316

Worthen, Shana, 'The Influence of Lynn White, jr.'s Medieval Technology and Social Change', in: History Compass, Vol. $7 / 4$ (2009), 1201-1217 